\title{
Okul Öncesi Eğitime 5-6 Yaşında Başlayan Çocuklar İle 3-4 Yaşında Başlayan Çocukların Öz Bakım Becerilerinin Veli Görüşlerine Göre İncelenmesi (Uşak İli Örneği)
}

\author{
Mustafa Yalçın* \\ Murat Başar* \\ Ayşe Çetinkaya ${ }^{* * *+}$
}

\section{Özet}

Bu araştırmada, okul öncesi eğitime 5-6 yaşındada başlayan çocuklar ile 3-4 yaşında başlayan çocukların öz bakım becerileri arasında anlamlı bir farklılığın olup olmadığı veli görüşlerine göre incelenmiştir.

Araştırmanın örneklemini 2010-2011 öğretim yılında Uşak ili Merkezinde ve Eşme ilçesindeki MEB'e bağlı 11 ilköğretim okulunun anasınıfında 5-6 yaş grubu 153 öğrencinin anne-babaları ve en az 2 yıl okul öncesi eğitimi alan 5-6 yaş grubu 100 öğrencinin anne-babaları ile gerçekleştirilmiştir.

Araştırmada çocukların öz bakım beceri düzeylerini belirlemek için “ Okul Öncesi Öz Bakım Becerileri Ölçeği” kullanılmıştır.

Veri toplama aracı ile elde edilen veriler SPSS 19 paket programına aktarılarak bağımsız örneklem grubu $t$ testi (independent samples $t$ test) ve güvenirlik analizine (cronbach alpha) tabi tutulmuştur.

Araştırma sonucuna göre, okul öncesi eğitime 5-6 yaşında başlayan çocuklar ile 3-4 yaşında başlayan çocukların yemek yeme, kendini tehlikelerden koruma, tuvalet alışkanlığı, giyinme soyunma, temizlik ve tertip-düzen ile ilgili öz bakım becerilerini kazanma düzeyleri okul öncesi eğitime 3-4 yaşında başlayan çocukların lehine çıkmıştır.

Sonuç olarak, okul öncesi eğitime 3-4 yaşında başlayan öğrencilerin öz bakım beceri düzeylerinin okul öncesi eğitime 5-6 yaşında başlayan öğrencilerin öz bakım beceri düzeylerinden daha gelişmiş olduğu, çocukların öz bakım beceri düzeylerinin okul öncesi eğitime başlama yaşı ile ilişkili olduğu sonucuna ulaşılmıştır.

\footnotetext{
${ }^{*}$ Yrd. Doç. Dr., Uşak Eğitim Fakültesi

** Yrd. Doç. Dr., Uşak Eğitim Fakültesi

${ }^{* * *}$ Meb Öğretmen
} 
Anahtar Kelimeler: Okul Öncesi Eğitim, Öz Bakım Becerisi, Okul Öncesi Eğitim Yaşı.

The Investigation Of The Self-Care Capabilities Of The Students Who Have Started Pre-School Education At The Age Of 3-4 And The Students Who Have Started Pre-School Education At The Age Of 5-6 Depending On Parents' Views

\title{
(The City Of Uşak Sample)
}

\begin{abstract}
In this research, depending on parents' views, it has been investigated whether or not there is a significant difference in self-care capabilities of the students starting pre-school education at the age of 5-6 and the students starting pre-school education at the age of 3-4

The research has been implemented in 2010-2011 education year spring term, with the parents of 153 students of 5-6 years old at 11 state elementary schools in Uşak city center and Eşme province and with 100 parents of students at 7 state and private schools in Uşak.

In the research "Pre-school Self-care Capability Scale" has been used to determine the level of the self-care capabilities of the students.

The data obtained by data collection has been subjected to independent samples group $t$ test and reliability analysis (cronbach alpha) by transferring to SPSS 19 package programmed

According to the results, the level of acquiring the capability of eating food, keeping himself from danger, bathroom using habit, getting dressed, cleaning and system and order is seen to be in favor of the students starting pre-school education at the age of 3-4 with regards to those at the age of 5-6, except from system and order.

As a consequence, it can be said that self-care capabilities of the students starting pre-school education at the age of 3-4 is more developed than those at 5-6 and self-care capabilities of the children is related to their age of starting pre-school education.
\end{abstract}


Key Words: Pre-school Education, Self-care Capabilities, Pre-school Education Age.

\section{Giriş}

Ülkemizde okul öncesi eğitimi sayısal olarak yükselten, ilköğretim okullarının bünyesinde yer alan mecburî ilköğretim çağına gelmemiş çocuklar için açılan anasınıflarıdır. Bu anasımıfları 5-6 yaş çocukların eğitimini kapsamaktadır. Okul öncesi olarak adlandırdığımız dönem ise 0-6 yaş grubunu kapsamaktadır. Bu dönem içerisinde ülkemizde okul öncesi eğitime başlamada 5-6 yaş döneminde yoğunluk görülmektedir. Bu dönem ise okul öncesi eğitimin son basamağıdır.

Her gelişim döneminde kazanılması gereken becerilerin farklı olduğu ve bu becerilerin birbirini tamamlayarak geliştiği göz önünde bulundurulduğunda ve okul öncesi dönemin insan hayatının kritik dönemi olduğu düşünüldügüünde bu dönem içinde verilecek eğitimin başlama yaşının da ne kadar önemli olduğu anlaşılacaktır.

Çocuğun 3-6 yaş arasında kazanması gereken öz bakım becerilerini bir yetişkine gereksinim duymadan ya da yetişkin yönergesi olmaksızın gerçekleştirmesi büyük önem taşımaktadır. Çünkü kazandığı bu beceriler diğer gelişim alanlarını da etkileyecek ve bu becerileri hayatı boyunca kullanacaktır. Bu nedenle çocukların öz bakım becerilerini sistemli ve doğru bir şekilde aile işbirliği ile okul öncesi eğitimi alarak öğrenmesi faydalı olacaktır.

Türkiye' de okul öncesi dönemde öz bakım becerileri ile ilgili yapılan araştırmaların oldukça az olduğu görülmektedir.

Demiriz ve Dinçer (2000), okul öncesi dönem çocuklarının öz bakım becerilerini annelerinin çalışıp çalı̧̧mama durumlarına göre incelemiştir. Araştırmanın örneklemini Ankara il merkezindeki orta sosyo-ekonomik düzeydeki 5-6 yaş çocuğuna sahip 298'i çalışan, 216'sı çalışmayan olmak üzere 514 anne oluşturmaktadır. Araştırmadan elde edilen bulgularda, çocukların yemek yeme, giyinme-soyunma, temizlik, tuvalet, tertip-düzen, tehlikelerden korunma gibi öz bakım becerileriyle ilgili birçok davranışı kazanma düzeyi ile annelerinin çalışıp-çalışmama durumları arasında anlamlı bir farklılığın olup olmadığı araştırılmıştır. Çalışan anne çocuklarının öz bakım toplam puanlarının çalışmayan anne çocuklarından daha yüksek olduğu sonucuna ulaşılmıştır.

Demiriz ve Dinçer (2001), 5-6 yaş çocuklarının Öz Bakım Becerilerini Cinsiyet ve Okul Öncesi Eğitim Alma Durumlarına göre 
incelemiştir. Araştırmanın örneklemini Ankara' daki resmi ve özel okul öncesi eğitim kurumuna devam eden ve okul öncesi eğitimi almayan toplam 513 çocuğun anne ve babaları oluşturmuştur. Araştırmada yemek yeme, giyinme-soyunma, temizlik, tuvalet alışkanlığı, tertip düzen, tehlikelerden korunma ile ilgili öz bakım becerilerine yönelik davranışlara yer verilerek ebeveynlere çocuklarının bu davranışları hangi sıklıkta gerçekleştirdikleri sorulmuştur. Sonuçta ise, çocukların öz bakım becerileri toplam puanları karşılaştırıldığında cinsiyet açısından anlamlı bir fark olmadığı görülmüştür. Ancak okul öncesi eğitimi alıp almama durumlarına göre anlamlı fark bulunmuştur. Okul öncesi eğitim alan çocukların öz bakım becerilerinde daha başarılı oldukları ortaya çıkmıştır.

Akar (2006), Özel ve resmi okul öncesi eğitim kurumlarına devam eden 4-6 yaş grubu çocuklarının beslenme alışkanlıklarının karşılaştırılması amacıyla yaptığı araştırmanın kapsamına Ankara'nın merkez ilçelerindeki özel ve resmi okul öncesi eğitim kurumlarına devam eden 4-6 yaş arasındaki 362 çocuk alınmıştır. Araştırma sonuçlarına göre, özel okullara giden çocukların \% 42'sinin, devlet okullarına giden çocukların \% 44'ünün bazen öğün atladığı, atlanan öğünün \% 36'l1k oranla öğle olduğu görülmüştür. Çocukların \% 55,4'ünün her gün sebze tüketmediği buna karşıllk özel okullara giden çocukların \% 33,8'inin haftada 1-2 kere hızlı-hazır yiyecekleri tükettikleri tespit edilmiştir. Özel ve resmi okul öncesi eğitim kurumlarına devam eden çocukların beslenme alışkanlıklarında öğün atlama durumu, en çok sevilen peynir çeşidi, fast-food yiyecekleri tüketme sıklığ konularında farklar olduğu sonucuna ulaşılmıştır.

Gazezoğlu (2007), okul öncesi eğitime devam eden 6 yaş çocuklarına öz bakım becerilerinin kazandırılmasında oyun ile öğretimin, geleneksel öğretime göre öğrencilerin erişileri üzerindeki etkisini belirlemeye çalışmıştır. Altı yaş grubu çocuklarının öz bakım becerilerini desteklemek amacı ile temizlik kurallarını uygulayabilme, giysilerinin giyme ve çıkarabilme, doğru beslenmenin önemini fark edebilme, dinlenme ile ilgili kuralları uygulayabilme, kendini kaza ve tehlikelerden koruyabilme gibi öz bakım becerilerinin beş alt boyutunu içeren bir oyun ile öğretim programı hazırlamıştır. Bu program sonucunda programa katılan çocuklar ile programa katılmayan çocukların puanları arasında program lehinde anlamlı bir fark bulunmuştur.

Konya (2007), kubaşık öğrenme etkinliklerinin 5 yaş çocuklarının öz bakım becerilerinin (yemek yeme, giyinme ve kişisel bakım) gelişimi üzerindeki etkisini araştırmıştır. Araştırmayı deney ve kontrol grubunda bulunan toplam 29 çocuk üzerinde gerçekleştirmiştir. Deney grubunda yer alan çocuklarla kubaşık öğrenme etkinlikleri, kontrol grubunda yer alan 
çocuklarla ise okul öncesi programında yer alan çoklu zekâ etkinlikleri uygulanmıştır. Deney ve kontrol gruplarına, araştırmacı tarafından geliştirilen "Öz bakım Becerileri Kontrol Listesi" ön test-son test olarak uygulanmıştır. Araştırmada öz bakım becerileri kontrol listesinden elde edilen erişi puanları üzerinde istatistiksel teknik olarak bağımsız gruplar ttesti kullanılmıştır. Analizlerde anlamlılık düzeyi $p<.05$ olarak alınmıştır. Sonuç olarak, öz bakım becerileri kontrol listesi yemek yeme, giyinme, kişisel bakım becerilerinden elde edilen toplam puanlar açısından deney grubu lehine anlamlı farklar bulunmuştur.

Shannon ve Chen (1988), 3 y1l süren beslenme eğitimiyle ilgili yaptıkları çalışmalarında, deney grubundaki çocuklara 3. 4. ve 5. yaşlarında, başlangıçta belirlenen beslenme bilgisi, kendi kendine yemek yeme davranışı konusunda her yıl 9-12 haftalık eğitim vermişlerdir. Uygulama sonrası eğitim alan çocukların kontrol grubundaki çocuklara göre daha yüksek puanlar aldıkları sonucuna ulaşmışlardır.

Lawatsch (1990), öğretmenin olumlu tutumunun bu konudaki etkinliğini araştırmak için okul öncesi çocuklarda beslenme bilgisi, yiyecekler konusundaki tutum ve davranışlar üzerine ödüllendirme ve tehdit etme uygulamalarının etkisini araştırmış, ödüllendirici yaklaşımın çocukların üzerinde olumlu etkileri olduğunu ortaya koymuştur.

Kingston (1995), sosyo-ekonomik düzeyi düşük düzeyde olan bir ilkokulun anasınıfındaki çocukların tuvalet alışkanlıklarını geliştirmek için bir program geliştirmişlerdir. Bu program, gelişim geriliği olan 3-5 yaş arasındaki 4 anasınıfı çocuğunun üzerinde denenmiştir. 12 haftalık bir süreç boyunca günlük tuvalet tablosu kullanılmıştır. Tuvalet esnasında her bir çocuk sözel yönergelerle pantolonlarını indirmeleri ve kaldırmaları için desteklenmiştir. Sonra sözel yönergeler kaldırılmış ve çocuk tuvalete gitme ihtiyacını söylediğinde övülmüş̧ür.

Geiger, Artz ve diğerleri (2000), çocukların bulaşıcı hastalıklara karsı korunmasını sağlamak amacıyla el yıkama becerisini kazandırma ile ilgili bir çalışma gerçekleştirmişlerdir. Bu çalışmada anaokulu çocuklarına el yıkama becerisini kazandırmak amacıyla bir etkinlik programı hazırlamışlardır. Bu etkinlik programındaki öğrenmeler, şarkı söyleyerek, oyunlar oynayarak ve rehber kullanarak gerçekleştirilmiştir. Çocukların bu yolla daha kolay ve eğlenerek öğrendikleri gözlenmiştir.

Okul öncesi eğitim ve öz bakım becerileri ile ilgili çeşitli araştırmalar yapılmıştır fakat okul öncesi eğitime erken yaşta başlamanın öz bakım becerilerinin gelişimi üzerine etkisini araştırmaya yönelik bir çalışmanın olmadığı görülmüştür. 
Okul öncesi eğitime 5-6 yaşında başlayan çocuklar ve daha erken yaşlarda başlayan çocukların öz bakım becerilerindeki gelişimi inceleyen bu araştırma sonucunda elde edilecek verilerin, Milli Eğitim Bakanlığı ve ilgili kurumlarının oluşturacakları yeni projelere katkı sağlayacağı düşünülmektedir.

$\mathrm{Bu}$ araştırma konusu ile ilgili yapılacak olan diğer araştırmalara kaynak olması düşünülerek araştırmacılara yol göstermesi umulmaktadır.

\section{ARAŞTIRMANIN AMACI}

Araştırmanın amacl; okul öncesi eğitime erken yaşta başlayan çocuklar ile 5-6 yaşlarında başlayan ilköğretim anasınıfı çocuklarının, öz bakım becerilerinin gelişimi açısından aralarında anlamlı bir farklılığın olup olmadığını veli görüşlerine göre araştırmaktır.

$\mathrm{Bu}$ amaç doğrultusunda öz bakım becerilerinin içinde yer alan aşağıdaki beceriler ile ilgili sorulara yanıt aranmıştır.

1. Okul öncesi eğitime 5-6 yaşında başlayan çocuklar ile 3-4 yaşlarında başlayan çocukların yemek yeme ile ilgili öz bakım becerilerinde aralarında anlamlı bir farklılık var mıdır?

2. Okul öncesi eğitime 5-6 yaşında başlayan çocuklar ile 3-4 yaşlarında başlayan çocukların tehlikelerden korunma ile ilgili öz bakım becerilerinde aralarında anlamlı bir farklılık var midir?

3. Okul öncesi eğitime 5-6 yaşında başlayan çocuklar ile 3-4 yaşlarında başlayan çocukların tuvalet alışkanlığı ile ilgili öz bakım becerilerinde aralarında anlamlı bir farklılık var mıdır?

4. Okul öncesi eğitime 5-6 yaşında başlayan çocuklar ile 3-4 yaşında başlayan çocukların giyinme soyunma ile ilgili öz bakım becerilerinde aralarında anlamlı bir farklılık var mıdır?

5. Okul öncesi eğitime 5-6 yaşında başlayan çocuklar ile 3-4 yaşında başlayan çocukların temizlik ile ilgili öz bakım becerilerinde aralarında anlamlı bir farklılık var mıdır?

6. Okul öncesi eğitime 5-6 yaşında başlayan çocuklar ile 3-4 yaşında başlayan çocukların tertip-düzen ile ilgili öz bakım becerilerinde aralarında anlamlı bir farklılık var mıdır?

7. Okul öncesi eğitime 5-6 yaşında başlayan çocuklar ile 3-4 yaşında başlayan çocukların genel öz yeterlilik aralarında anlamlı bir farklılık var mıdır? 


\section{YÖNTEM}

Okul öncesi eğitime 5-6 yaşında başlayan çocuklar ile daha erken yaşta başlayan çocukların öz bakım becerileri arasında anlamlı bir farklılığın olup olmadığını araştıran bu çalışma tarama modeli ile yapılmıştır. “Tarama modeli, geçmişte ya da halen var olan bir durumu var olduğu şekliyle betimlemeyi, amaçlayan araştırma yaklaşımıdır. Araştırmaya konu olan olay, birey ya da nesne, kendi koşulları içinde ve olduğu gibi tanımlanmaya çalışılır. Onları, herhangi bir şekilde değiştirme, etkileme çabası gösterilmez" (Karasar, 2002).

\section{Evren}

Araştırmanın evrenini, 2010-2011 öğretim yılında Uşak ili genelinde bulunan okul öncesi eğitimi kurumlarına 5-6 yaşında başlayan öğrencilerin anne-babaları ile en az 2 yıl okul öncesi eğitimi alan 5- 6 yaş grubu çocukların anne-babaları oluşturmaktadır.

\section{Örneklem}

Örneklemin evreni temsil edebilecek nitelikte olması amacıyla okulların seçiminde çevre şartları göz önünde bulundurulmuştur.

Çalışmanın örneklemini, Uşak ili Merkez'inde bünyesinde anasınıfı bulunan 8 ilköğretim okulu ve Eşme ilçesi merkezinde 3 ilköğretim okulunun 153 öğrencinin anne-babası ile Uşak Merkez'inde bulunan 7 bağımsız anaokulunun 100 öğrencinin anne-babası oluşturmaktadır.

\section{VERI TOPLAMA ARAÇLARI}

Bu çalışmada veri toplama aracı olarak, “Okul Öncesi Öz Bakım Becerileri Ölçeği" kullanılmıştır. Araştırmacı tarafından geliştirilen "Okul Öncesi Öz Bakım Becerileri Ölçeği" çocukların öz bakım becerilerini ölçmede kullanılmıştır. Okul Öncesi Öz Bakım Becerileri Ölçeği; Portage Kontrol Listesi'nden, Denver II Gelişimsel Tarama Testi'nin öz bakım becerileri ile ilgili bölümünden, MEB tarafından hazırlanmış olan 36-72 aylık çocuklar için okul öncesi eğitim programı (MEB, 2006) ve Demiriz ve Dinçer' in (2000), araştırmalarında kullandıkları anket formu incelenerek oluşturulmuştur.

“Okul Öncesi Öz Bakım Becerileri Ölçeği” 6 bölümden ve toplam 45 Maddeden oluşmaktadır. Boyutlar, madde sayıları ve güvenirlik analizi sonuçları Tablo 3.1.' de verilmiştir.

Bunlar Yemek Yeme İle ilgili Beceriler (10 Madde), Kendini Tehlikelerden Koruma İle İlgili Beceriler (6 Madde), Tuvalet Alışkanlığ İle İlgili Beceriler (7 Madde), Giyinme Soyunma İle İlgili Beceriler (6 Madde) Temizlik İle İlgili Beceriler (10 Madde) ve Tertip Düzen İle İlgili Beceriler (6 Madde) şeklindedir. Kontrol listesindeki becerilerin gelişmişlik düzeylerini 
belirleyebilmek için "Çok Yeterli, Yeterli, Biraz Yeterli, Yetersiz, Çok Yetersiz" seçenekleri kullanılmıştır. Çok Yeterli "5 Puan", Yeterli "4 Puan”, Biraz Yeterli "3 Puan",Yetersiz "2 Puan" ve Çok Yetersiz "1 Puan" olarak değerlendirilmiştir.

Tablo 1. Okul Öncesi Öz Bakım Becerileri Ölçeği Madde Sayıları ve Güvenirlik Analizi

\begin{tabular}{|l|c|c|}
\hline Boyut & Madde Sayısı & A \\
\hline Yemek Yeme İle ilgili Beceriler & 10 & .85 \\
\hline $\begin{array}{l}\text { Kendini Tehlikelerden Koruma İle İlgili } \\
\text { Beceriler }\end{array}$ & 6 & .75 \\
\hline Tuvalet Alışkanlığı İle İlgili Beceriler & 7 & .88 \\
\hline Giyinme Soyunma İle İlgili Beceriler & 6 & .93 \\
\hline Temizlik İle İlgili Beceriler & 10 & .94 \\
\hline Tertip Düzen İle İlgili Beceriler & 6 & .88 \\
\hline Toplam & 45 & .97 \\
\hline
\end{tabular}

BÖLÜM: BULGULAR

$\mathrm{Bu}$ bölümde verilerin analizinden elde edilen bulgulara yer verilmiştir.

Araştırmada elde edilen bulgulara araştırma sorularına uygun bir sıralamayla yer verilmiştir.

Tablo 2. Öz Bakım Becerileri Boyutlarından Alınan Puanların Okul Öncesi Eğitime Başlama Yaşına Göre Farklılaşmasını Gösteren Bağımsız Örneklem Grubu t Testi Sonuçları

\begin{tabular}{|c|c|c|c|c|c|c|c|}
\hline & $\begin{array}{c}\text { Okul Öncesi Ĕ̆itime } \\
\text { Başlama Yaşı }\end{array}$ & $\mathrm{N}$ & $\begin{array}{c}\text { Ortalam } \\
\mathrm{a}\end{array}$ & $\begin{array}{c}\text { St. } \\
\text { Sapma }\end{array}$ & $\begin{array}{c}\text { St. } \\
\text { Hata } \\
\text { Ort. }\end{array}$ & $\mathrm{T}$ & $\mathrm{P}$ \\
\hline $\begin{array}{c}\text { Yemek } \\
\text { Yeme }\end{array}$ & $\begin{array}{c}\text { 5-6 yaşında } \\
\text { başlayanlar }\end{array}$ & 153 & 3.8712 & .80063 & .06473 & -3.589 & .000
\end{tabular}




\begin{tabular}{|c|c|c|c|c|c|c|c|}
\hline & $\begin{array}{l}\text { 3-4 yaşında } \\
\text { başlayanlar }\end{array}$ & 100 & 4.1830 & .57946 & .05795 & & \\
\hline \multirow{2}{*}{$\begin{array}{c}\text { Kaza ve } \\
\text { Tehlikelerde } \\
\text { n Korunma }\end{array}$} & $\begin{array}{l}\text { 5-6 yaşında } \\
\text { başlayanlar }\end{array}$ & 153 & 3.2135 & .91236 & .07376 & \multirow{2}{*}{-5.012} & \multirow{2}{*}{.000} \\
\hline & $\begin{array}{l}\text { 3-4 yaşında } \\
\text { başlayanlar }\end{array}$ & 100 & 3.7550 & .78940 & .07894 & & \\
\hline \multirow{2}{*}{ Tuvalet } & $\begin{array}{l}\text { 5-6 yaşında } \\
\text { başlayanlar }\end{array}$ & 153 & 4.4323 & .83845 & .06778 & \multirow{2}{*}{-2.344} & \multirow{2}{*}{.020} \\
\hline & $\begin{array}{l}\text { 3-4 yaşında } \\
\text { başlayanlar }\end{array}$ & 100 & 4.6229 & .44879 & .04488 & & \\
\hline \multirow{2}{*}{$\begin{array}{l}\text { Giyinme } \\
\text { Soyunma }\end{array}$} & $\begin{array}{l}\text { 5-6 yaşında } \\
\text { başlayanlar }\end{array}$ & 153 & 3.8214 & .96505 & .07802 & \multirow{2}{*}{-2.345} & \multirow{2}{*}{.020} \\
\hline & $\begin{array}{l}\text { 3-4 yaşında } \\
\text { başlayanlar }\end{array}$ & 100 & 4.0800 & .77975 & .07798 & & \\
\hline \multirow{2}{*}{ Temizlik } & $\begin{array}{l}\text { 5-6 yaşında } \\
\text { başlayanlar }\end{array}$ & 153 & 3.7366 & .98400 & .07955 & \multirow{2}{*}{-2.847} & \multirow{2}{*}{.005} \\
\hline & $\begin{array}{l}\text { 3-4 yaşında } \\
\text { başlayanlar }\end{array}$ & 100 & 4.0370 & .69292 & .06929 & & \\
\hline \multirow{2}{*}{$\begin{array}{l}\text { Tertip } \\
\text { Düzen }\end{array}$} & $\begin{array}{l}\text { 5-6 yaşında } \\
\text { başlayanlar }\end{array}$ & 153 & 3.6797 & .99533 & .08047 & \multirow{2}{*}{-1.593} & \multirow{2}{*}{.113} \\
\hline & $\begin{array}{l}\text { 3-4 yaşında } \\
\text { başlayanlar }\end{array}$ & 100 & 3.8650 & .83977 & .08398 & & \\
\hline
\end{tabular}

Tablo 2' de görüldüğü gibi;

1-) Okul öncesi eğitime 3-4 başlayan öğrenciler ile 5-6 yaşında başlayan öğrencilerin yemek yeme ile ilgili olumlu davranış gösterme düzeyleri arasında manidar fark vardır. Söz konusu fark okul öncesi eğitime 
3-4 yaşında başlayan öğrenciler lehinedir. Okul öncesi eğitime önce başlayan öğrencilerin geç başlayan öğrencilere göre beslenme ile ilgili becerilerde daha olumlu davranışlar gösterdikleri bulunmuştur. ( $t=-3.589, \mathrm{p}<.001)$.

2-) Okul öncesi eğitime 3-4 başlayan öğrenciler ile 5-6 yaşında başlayan öğrencilerin kendini tehlikelerden koruma ile ilgili olumlu davranış gösterme düzeyleri arasında manidar fark vardır. Söz konusu fark okul öncesi eğitime 3-4 yaşında başlayan öğrenciler lehinedir. Okul öncesi eğitime önce başlayan öğrencilerin geç başlayan öğrencilere göre kendini tehlikelerden koruma ile ilgili becerilerde daha olumlu davranışlar gösterdikleri bulunmuştur ( $\mathrm{t}=-5.012, \mathrm{p}<.001)$.

3-) Okul öncesi eğitime 3-4 başlayan öğrenciler ile 5-6 yaşında başlayan öğrencilerin tuvalet alışkanlığı ile ilgili olumlu davranış gösterme düzeyleri arasında manidar fark vardır. Söz konusu fark okul öncesi eğitime 3-4 yaşında başlayan öğrenciler lehinedir. Okul öncesi eğitime önce başlayan öğrencilerin geç başlayan öğrencilere göre tuvalet alışkanlığı ile ilgili becerilerde daha olumlu davranışlar gösterdikleri bulunmuştur ( $t=-2.344$, $\mathrm{p}<.05)$.

4-) Okul öncesi eğitime 3-4 başlayan öğrenciler ile 5-6 yaşında başlayan öğrencilerin giyinme ve soyunma ile ilgili olumlu davranış gösterme düzeyleri arasında manidar fark vardır. Söz konusu fark okul öncesi eğitime 3-4 yaşında başlayan öğrenciler lehinedir. Okul öncesi eğitime önce başlayan öğrencilerin geç başlayan öğrencilere göre giyinme ve soyunma ile ilgili becerilerde daha olumlu davranışlar gösterdikleri bulunmuştur ( $\mathrm{t}=-2.345, \mathrm{p}<.05)$.

5-) Okul öncesi eğitime 3-4 başlayan öğrenciler ile 5-6 yaşında başlayan öğrencilerin temizlik ile ilgili olumlu davranış gösterme düzeyleri arasında manidar fark vardır. Söz konusu fark okul öncesi eğitime 3-4 yaşında başlayan öğrenciler lehinedir. Okul öncesi eğitime önce başlayan öğrencilerin geç başlayan öğrencilere göre temizlik ile ilgili becerilerde daha olumlu davranışlar gösterdikleri bulunmuştur ( $\mathrm{t}=-2.847, \mathrm{p}<.05)$.

6-) Okul öncesi eğitime 3-4 başlayan öğrenciler ile 5-6 yaşında başlayan öğrencilerin tertip ve düzen ile ilgili olumlu davranış gösterme düzeyleri arasında manidar fark yoktur ( $\mathrm{t}=-1.593, \mathrm{p}>05)$.

Tablo 3. Okul Öncesi Eğitime 5-6 Yaşında Başlayan Çocuklar ile 3-4 Yaşında Başlayan Çocukların Yemek Yeme ile İlgili Öz Bakım Becerilerini Kazanım Durumları

\section{OKUL ÖNCESİ EĞİTIME}




\begin{tabular}{|c|c|c|c|c|c|c|c|c|c|c|c|}
\hline BAŞLAMA YAŞI & \multicolumn{5}{|c|}{$\begin{array}{c}\text { 5-6 YAŞINDA } \\
\text { BAŞLAYANLAR }\end{array}$} & \multicolumn{5}{|c|}{$\begin{array}{c}\text { 3-4 YAŞINDA } \\
\text { BAŞLAYANLAR }\end{array}$} & \multirow[t]{2}{*}{$\mathbf{P}$} \\
\hline BECERİ DURUMU & 1 & 2 & 3 & 4 & & 1 & 2 & 3 & 4 & 5 & \\
\hline $\begin{array}{c}\text { YEMEK YEME İLE İLGÍLI } \\
\text { BECERILLER }\end{array}$ & $\%$ & $\%$ & $\%$ & $\%$ & $\%$ & $\%$ & $\%$ & $\%$ & $\%$ & $\%$ & \\
\hline $\begin{array}{l}\text { Yemeğin türüne uygun çatal, } \\
\text { kaşık vb. araç gereci alır. }\end{array}$ & 3 & 3 & 3 & 25 & 67 & 0 & 2 & 5 & 29 & 64 & $\begin{array}{l}0,194^{*} \\
p>0,05\end{array}$ \\
\hline $\begin{array}{l}\text { Yemekte başkasına ait bardak, } \\
\text { çatal vb.lerini kullanmaz. }\end{array}$ & 9 & ,7 & 3 & 12 & 76 & 1 & 2 & 3 & 16 & 78 & $\begin{array}{l}0,001^{* *} \\
P<0,05\end{array}$ \\
\hline $\begin{array}{l}\text { Ekmeğinin üzerine yumuşak } \\
\text { besinleri sürer. }\end{array}$ & 5 & 9 & 12 & 29 & 45 & 1 & 6 & 12 & 29 & 52 & $\begin{array}{l}0,228^{*} \\
p>0,05\end{array}$ \\
\hline $\begin{array}{l}\text { Bıçak kullanarak yumuşak } \\
\text { besinleri keser. }\end{array}$ & 7 & 12 & 14 & 32 & 35 & 0 & 10 & 14 & 34 & 42 & $\begin{array}{l}0,004^{* *} \\
P<0,05\end{array}$ \\
\hline $\begin{array}{l}\text { Acıktığında kendi için soğuk } \\
\text { sandviç hazırlar. }\end{array}$ & 25 & 20 & 17 & 22 & 17 & 9 & 21 & 22 & 31 & 17 & $\begin{array}{l}0,013^{* *} \\
P<0,05\end{array}$ \\
\hline $\begin{array}{l}\text { Yemek istediği yiyecekleri } \\
\text { tabağına alır. }\end{array}$ & 11 & 14 & 20 & 29 & 27 & 3 & 9 & 11 & 31 & 46 & $\begin{array}{l}0,001^{* *} \\
P<0,05\end{array}$ \\
\hline $\begin{array}{l}\text { Su, süt veya meyve suyunu } \\
\text { dökmeden bardağina } \\
\text { doldurur. }\end{array}$ & 5 & 7 & $\begin{array}{l}11 \\
4\end{array}$ & 28 & 47 & $\mathbf{0}$ & 4 & 8 & 33 & 55 & $\begin{array}{l}0,009^{* *} \\
P<0,05\end{array}$ \\
\hline $\begin{array}{l}\text { Yemeğini yiyebileceği kadar } \\
\text { yemek alır. }\end{array}$ & 7 & 9 & 24 & 3 & 3 & 4 & 7 & 24 & 23 & 42 & $\begin{array}{l}0,549^{*} \\
p>0,05\end{array}$ \\
\hline $\begin{array}{l}\text { Yiyecekleri yerken görgü } \\
\text { kurallarına uyar }\end{array}$ & 4 & 6 & 15 & 28 & 48 & 0 & 2 & 12 & 31 & 55 & $\begin{array}{l}0,009^{* *} \\
P<0,05\end{array}$ \\
\hline $\begin{array}{l}\text { Yemeğini öğün zamanlarında } \\
\text { yer. }\end{array}$ & 10 & 7 & 13 & 35 & 36 & 4 & 4 & 10 & 29 & 53 & $\begin{array}{l}0,59^{*} \\
p>0,05\end{array}$ \\
\hline
\end{tabular}


${ }^{*} \mathrm{p}<.05{ }^{* *} \mathrm{p}<.01$

Tablo 3.'te yer alan yemek yeme ile ilgili öz bakım becerilerinden olan yemekte başkasına ait bardak, çatal vb.lerini kullanmama, bıçak kullanarak yumuşak besinleri kesme, acıktığında kendi için soğuk sandviç hazırlama, yiyecekleri tabağına alma, bardağına dökmeden su, süt veya meyve suyu doldurma, yiyecekleri yerken görgü kurallarına uyma davranışları ile okul öncesi eğitime başlama yaşı arasında istatiksel olarak anlamlı fark bulunmuştur. Bu fark okul öncesi eğitime 3-4 yaşında başlayanların lehinedir. Bu sonuçlara göre okul öncesi eğitime 3-4 yaşında başlayan çocukların, okul öncesi eğitime 5-6 yaşında başlayan çocuklara göre yemek yeme ile ilgili öz bakım becerilerinde daha başarılı oldukları söylenebilir.

Tablo 4. Okul Öncesi Eğitime 5-6 Yaşında Başlayan Çocuklar ile 3-4 Yaşında Başlayan Çocukların Kazalardan Ve Tehlikelerden Korunma ile İlgili Öz Bakım Becerilerini Kazanım Durumları

\begin{tabular}{|c|c|c|c|c|c|c|c|c|c|c|c|}
\hline $\begin{array}{c}\text { OKUL ÖNCESI } \\
\text { EĞİTIME BAŞLAMA } \\
\text { YAŞI }\end{array}$ & \multicolumn{5}{|c|}{$\begin{array}{c}\text { 5-6 YAŞINDA } \\
\text { BAŞLAYANLAR }\end{array}$} & \multicolumn{5}{|c|}{$\begin{array}{c}\text { 3-4 YAŞINDA } \\
\text { BAŞLAYANLAR }\end{array}$} & \multirow[t]{2}{*}{$\mathbf{P}$} \\
\hline BECERİ DURUMU & 1 & 2 & 3 & 4 & 5 & 1 & 2 & 3 & 4 & 5 & \\
\hline $\begin{array}{c}\text { KAZALARDAN VE } \\
\text { TEHLIKELERDEN } \\
\text { KORUNMA İLE } \\
\text { İLGİLI் BECERİLER }\end{array}$ & $\%$ & $\%$ & $\%$ & $\%$ & $\%$ & $\%$ & $\%$ & $\%$ & $\%$ & $\%$ & \\
\hline $\begin{array}{l}\text { Evinin yakınlarında } \\
\text { sürekli yetişkin } \\
\text { denetimi olmadan } \\
\text { dolaşabilir. }\end{array}$ & 20 & 12 & 12 & 26 & 30 & 9 & 15 & 12 & 35 & 29 & $\begin{array}{l}0,006^{* *} \\
P<0,05\end{array}$ \\
\hline Ev adresini bilir. & 20 & 12 & 27 & 23 & 19 & 7 & 13 & 32 & 19 & 29 & $\begin{array}{l}0,426^{* *} \\
P<0,5\end{array}$ \\
\hline
\end{tabular}




\begin{tabular}{|c|c|c|c|c|c|c|c|c|c|c|c|}
\hline $\begin{array}{l}\text { Ev telefonunu veya } \\
\text { anne-babasına ait cep } \\
\text { telefonunu söyler. }\end{array}$ & 35 & 16 & 19 & 18 & 12 & 11 & 23 & 20 & 22 & 24 & $\begin{array}{l}0,194^{*} \\
P>0,05\end{array}$ \\
\hline $\begin{array}{l}\text { Tehlikeli eşyalardan } \\
\text { kendini korur (bıçak, } \\
\text { yanıcı madde vb.) }\end{array}$ & 7 & 7 & 16 & 28 & 43 & 2 & 1 & 8 & 24 & 65 & $\begin{array}{l}0,001^{* *} \\
\mathbf{P}<0,05\end{array}$ \\
\hline $\begin{array}{l}\text { Tehlikeli durumlarda } \\
\text { gerekli olan numaraları } \\
\text { bilir (155 polis,112 } \\
\text { itfaiye vb.) }\end{array}$ & 20 & 24 & 18 & 18 & 22 & 10 & 14 & 17 & 21 & 38 & $\begin{array}{l}0,648^{*} \\
p>0,05\end{array}$ \\
\hline $\begin{array}{l}\text { Araçta emniyet } \\
\text { kemerini kullanır. }\end{array}$ & 16 & 12 & 23 & 20 & 29 & 7 & 4 & 12 & 30 & 47 & $\begin{array}{l}0,00^{* *} \\
P<0,01\end{array}$ \\
\hline
\end{tabular}

${ }^{*} \mathrm{p}<.05{ }^{* *} \mathrm{p}<.01$

Çocukların kazalardan ve tehlikelerden korunma ile ilgili öz bakım becerilerini okul öncesi eğitime başlama yaşına göre gösteren Tablo 4 'te; evinin yakınlarında sürekli yetişkin denetimi olmadan dolaşabilme, ev adresini bilme, tehlikeli eşyalardan kendini koruma, araçta emniyet kemerini kullanma davranışları ile okul öncesi eğitime başlama yaşı arasında anlamlı fark bulunmuştur. Bu fark okul öncesi eğitime 3-4 yaşında başlayanların lehinedir. Bu bulgulara göre okul öncesi eğitime 3-4 yaşında başlayan çocukların, okul öncesi eğitime 5-6 yaşında başlayan çocuklara göre kazalardan ve tehlikelerden korunma ile ilgili öz bakım becerilerinde daha başarılı oldukları söylenebilir.

Tablo 5. Okul Öncesi Eğitime 5-6 Yaşında Başlayan Çocuklar ile 3-4 Yaşında Başlayan Çocukların Tuvalet Alışkanlığı ile İlgili Öz Bakım Becerilerini Kazanım Durumları

\begin{tabular}{|c|c|c|c|c|c|c|c|c|c|c|l|}
\hline OKUL ÖNCESI & \multicolumn{9}{|c|}{} & \multicolumn{3}{|c|}{ 3-4 YAŞINDA } & \multirow{2}{*}{ P } \\
EĞİTIME BAŞLAMA & \multicolumn{3}{|c|}{ 5-6 YAŞINDA } & \multicolumn{3}{|c|}{ BAŞLAYANLAR } & PAŞLAYANLAR \\
YAŞI & 1 & 2 & 3 & 4 & 5 & 1 & 2 & 3 & 4 & 5 & \\
\hline BECERI DURUMU & 1 &
\end{tabular}




\begin{tabular}{|c|c|c|c|c|c|c|c|c|c|c|c|}
\hline 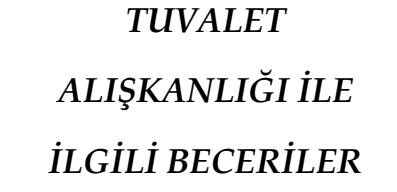 & $\%$ & $\%$ & $\%$ & $\%$ & $\%$ & $\%$ & $\%$ & $\%$ & $\%$ & $\%$ & \\
\hline $\begin{array}{l}\text { Tuvalet ihtiyacını } \\
\text { zamanında giderir. }\end{array}$ & 5 & ,7 & 3 & 12 & 79 & 0 & 1 & 3 & 15 & 81 & $\begin{array}{l}0,001^{* *} \\
\mathrm{P}<0,05\end{array}$ \\
\hline $\begin{array}{l}\text { Tuvalet ihtiyacını } \\
\text { giderdikten sonra } \\
\text { tuvalet kağıdı ve su } \\
\text { kullanarak yardımsız } \\
\text { temizliğini yapar. }\end{array}$ & 7 & 5 & 9 & 16 & 63 & 0 & 6 & 6 & 29 & 59 & $\begin{array}{l}0,001^{* *} \\
\mathrm{P}<0,05\end{array}$ \\
\hline $\begin{array}{l}\text { Tuvalet ihtiyacını } \\
\text { giderdikten sonra iç } \\
\text { çamaşırını ve alt } \\
\text { giysisini uygun şekilde } \\
\text { giyer. }\end{array}$ & 5 & 3 & 5 & 18 & 70 & 1 & 1 & 5 & 23 & 70 & $\begin{array}{l}0,017^{* *} \\
\mathrm{P}<0,05\end{array}$ \\
\hline $\begin{array}{l}\text { Tuvalet ihtiyacını } \\
\text { yapmadan önce ve } \\
\text { tuvaletini yaptıktan } \\
\text { sonra sifonu çekerek } \\
\text { tuvaleti temiz bırakır. }\end{array}$ & 5 & 1 & 7 & 18 & 70 & 1 & 2 & 4 & 21 & 72 & $\begin{array}{l}0,024^{* *} \\
\mathrm{P}<0,05\end{array}$ \\
\hline $\begin{array}{l}\text { Tuvaletten sonra } \\
\text { ellerini uygun şekilde } \\
\text { yıkar. }\end{array}$ & 4 & 1 & 5 & 17 & 73 & 0 & 1 & 2 & 16 & 81 & $\begin{array}{l}0,000^{* *} \\
\mathrm{P}<0,05\end{array}$ \\
\hline $\begin{array}{l}\text { Umumi yerlerde bay ve } \\
\text { bayan tuvaletlerini ayırt } \\
\text { eder. }\end{array}$ & 5 & 3 & 5 & 26 & 61 & 1 & 5 & 9 & 11 & 74 & $\begin{array}{l}0,360 \\
p>0,05\end{array}$ \\
\hline $\begin{array}{l}\text { Tuvalete gitmesi } \\
\text { gerektiğinde } \\
\text { uykusundan uyanır ve } \\
\text { gece altı kuru kalır. }\end{array}$ & 5 & 3 & 7 & 17 & 68 & 0 & 3 & 6 & 10 & 81 & $\begin{array}{l}0,000^{* *} \\
P<0,05\end{array}$ \\
\hline
\end{tabular}
${ }^{*} \mathrm{p}<.05 \quad{ }^{* *} \mathrm{p}<.01$

Çocukların tuvalet alışkanlığı ile ilgili öz bakım becerilerini okul öncesi eğitime başlama yaşına göre gösteren Tablo 5'te; tuvalet ihtiyacının farkında olma, tuvalet ihtiyacını giderdikten sonra tuvalet kâğıdı ve su 
kullanarak yardımsız temizliğini yapma, tuvalet ihtiyacını giderdikten sonra iç çamaşırını ve alt giysisini uygun şekilde giyme, tuvalet ihtiyacını yapmadan önce ve tuvaletini yaptıktan sonra sifonu çekerek tuvaleti temiz bırakma, tuvaletten sonra ellerini uygun şekilde yıkama, tuvalete gitmesi gerektiğinde uykusundan uyanma davranışları ile okul öncesi eğitime başlama yaşı arasında anlamlı fark bulunmuştur. Bu fark okul öncesi eğitime 3-4 yaşında başlayanların lehinedir. Bu sonuçlara göre okul öncesi eğitime 3-4 yaşında başlayan çocukların, okul öncesi eğitime 5-6 yaşında başlayan çocuklara göre tuvalet alışkanlığı ile ilgili öz bakım becerilerinde daha başarılı oldukları söylenebilir.

Tablo 6. Okul Öncesi Eğitime 5-6 Yaşında Başlayan Çocuklar ile 3-4 Yaşında Başlayan Çocukların Giyinme Soyunma ile İlgili Öz Bakım Becerilerini Kazanım Durumları

\begin{tabular}{|c|c|c|c|c|c|c|c|c|c|c|c|}
\hline $\begin{array}{c}\text { OKUL ÖNCESI } \\
\text { EĞITIME BAŞLAMA } \\
\text { YAŞI }\end{array}$ & \multicolumn{5}{|c|}{$\begin{array}{c}\text { 5-6 YAŞINDA } \\
\text { BAŞLAYANLAR }\end{array}$} & & & $Y A$ & VLA & & \multirow[t]{2}{*}{$\mathbf{P}$} \\
\hline BECERİ DURUMU & 1 & 2 & 3 & 4 & 5 & 1 & 2 & 3 & 4 & 5 & \\
\hline $\begin{array}{c}\text { GIYINME SOYUNMA } \\
\text { ILE İLGİLI } \\
\text { BECERILLER }\end{array}$ & $\%$ & $\%$ & $\%$ & $\%$ & $\%$ & $\%$ & $\%$ & $\%$ & $\%$ & $\%$ & \\
\hline $\begin{array}{l}\text { Ayakkabılarını kendi } \\
\text { giyer. }\end{array}$ & 3 & 11 & 16 & 23 & 47 & 0 & 6 & 23 & 32 & 39 & $\begin{array}{l}0,014^{* *} \\
P<0,05\end{array}$ \\
\hline $\begin{array}{l}\text { Ayakkabılarının } \\
\text { bağcıklarını } \\
\text { yardımsız bağlar. }\end{array}$ & 9 & 16 & 28 & 28 & 20 & 1 & 8 & 25 & 36 & 30 & $\begin{array}{l}0,002^{* *} \\
P<0,05\end{array}$ \\
\hline $\begin{array}{l}\text { Duruma ve hava } \\
\text { şartlarına uygun } \\
\text { giyeceği seçer. }\end{array}$ & 9 & 8 & 20 & 36 & 27 & 0 & 3 & 15 & 45 & 37 & $\begin{array}{l}0,000^{* *} \\
\mathrm{P}<0,05\end{array}$ \\
\hline
\end{tabular}


Çocukların giyinme soyunma ile ilgili öz bakım becerilerini okul öncesi eğitime başlama yaşına göre gösteren Tablo $6^{\prime}$ da; ayakkabılarını kendi giyme, ayakkabılarının bağcıklarını yardımsız bağlama, duruma ve hava şartlarına uygun giyeceği seçme davranışları ile okul öncesi eğitime başlama yaşı arasında anlamlı fark bulunmuştur. Bu fark okul öncesi eğitime 3-4 yaşında başlayanların lehinedir. Bu sonuçlara göre okul öncesi eğitime 3-4 yaşlarında başlayan çocukların, okul öncesi eğitime 5-6 yaşında başlayan çocuklara göre giyinme soyunma ile ilgili öz bakım becerilerinde daha başarılı oldukları söylenebilir.

Tablo 7. Okul Öncesi Eğitime 5-6 Yaşında Başlayan Çocuklar ile 3-4 Yaşında Başlayan Çocukların Temizlik ile İlgili Öz Bakım Becerilerini Kazanım Durumları

\begin{tabular}{|c|c|c|c|c|c|c|c|c|c|c|c|}
\hline $\begin{array}{c}\text { OKUL ÖNCESİ EĞİTIME } \\
\text { BAŞLAMA YAŞI }\end{array}$ & \multicolumn{5}{|c|}{$\begin{array}{c}\text { 5-6 YAŞINDA } \\
\text { BAŞLAYANLAR }\end{array}$} & \multicolumn{5}{|c|}{$\begin{array}{c}\text { 3-4 YAŞINDA } \\
\text { BAŞLAYANLAR }\end{array}$} & $\mathbf{P}$ \\
\hline BECERİ DURUMU & 1 & 2 & 3 & 4 & 5 & 1 & 2 & 3 & 4 & 5 & \\
\hline $\begin{array}{c}\text { TEMİZLIKK İLE İLGI்İ } \\
\text { BECERÍLER }\end{array}$ & $\%$ & $\%$ & $\%$ & $\%$ & $\%$ & $\%$ & $\%$ & $\%$ & $\%$ & $\%$ & \\
\hline $\begin{array}{l}\text { Sabah kalktığında } \\
\text { hatırlatılmadan yüzünü } \\
\text { yıkar. }\end{array}$ & 6 & 5 & 18 & 36 & 35 & 0 & 4 & 12 & 46 & 38 & $\begin{array}{l}0,008^{* *} \\
P<0,05\end{array}$ \\
\hline $\begin{array}{l}\text { Yemekten önce ve sonra } \\
\text { hatırlatılmadan ellerini } \\
\text { yıkar. }\end{array}$ & 3 & 9 & 19 & 29 & 41 & 0 & 3 & 16 & 43 & 38 & $\begin{array}{l}0,002^{* *} \\
\mathrm{P}<0,05\end{array}$ \\
\hline $\begin{array}{l}\text { Dişlerini yardımsız } \\
\text { günde en az } 2 \text { defa } \\
\text { fırçalar. }\end{array}$ & 7 & 13 & 22 & 26 & 32 & 2 & 2 & 8 & 43 & 45 & $\begin{array}{l}0,000^{* *} \\
\mathrm{P}<0,05\end{array}$ \\
\hline $\begin{array}{l}\text { Hatırlatılmadan } \\
\text { gerektiğinde yardımsız } \\
\text { burnunu mendile siler. }\end{array}$ & 5 & 7 & 15 & 35 & 39 & 0 & 2 & 8 & 44 & 46 & $\begin{array}{l}0,007^{* *} \\
P<0,05\end{array}$ \\
\hline
\end{tabular}




\begin{tabular}{|l|c|c|c|c|c|c|c|c|c|c|l|}
\hline $\begin{array}{l}\text { Öksürürken ve } \\
\text { hapşırırken eliyle ya da } \\
\text { mendille ağzını kapatır. }\end{array}$ & 5 & 11 & 16 & 37 & 32 & 1 & 3 & 9 & 46 & 41 & $\begin{array}{l}0,001^{* *} \\
\mathbf{P}<0,05\end{array}$ \\
\hline $\begin{array}{l}\text { Sırt, boyun ve ense hariç } \\
\text { kendini yıkar. }\end{array}$ & 12 & 15 & 21 & 24 & 28 & 3 & 18 & 26 & 31 & 22 & $\begin{array}{l}0,008^{* *} \\
\mathbf{P}<0,05\end{array}$ \\
\hline $\begin{array}{l}\text { Saçlarını tarar. } \\
\text { Saçlarını yardımsız } \\
\text { kurutur. }\end{array}$ & 11 & 14 & 26 & 24 & 26 & 2 & 11 & 27 & 33 & 27 & $\begin{array}{l}0,004^{* *} \\
\mathbf{P}<0,05\end{array}$ \\
\hline $\begin{array}{l}\text { Tirnakları uzadığında } \\
\text { kesilmesi gerektiğini } \\
\text { bilir. }\end{array}$ & 6 & 5 & 20 & 33 & 36 & 0 & 0 & 13 & 52 & 35 & $\begin{array}{l}0,000^{* *} \\
\mathbf{P}<0,05\end{array}$ \\
\hline
\end{tabular}

${ }^{*} \mathrm{p}<.05 \quad{ }^{* *} \mathrm{p}<.01$

Çocukların temizlik ile ilgili öz bakım becerilerini okul öncesi eğitime başlama yaşına göre gösteren Tablo $7^{\prime}$ de; sabah kalktığında hatırlatılmadan yüzünü yıkama, yemekten önce ve sonra hatırlatılmadan ellerini yıkama, dişlerini yardımsız günde en az 2 defa fırçalama, öksürürken ve hapşırırken eliyle ya da mendille ağzını kapatma, sırt, boyun ve ense hariç kendini yıkama, saçlarını tarama, saçlarını yardımsız kurutma, tırnakları uzadığında kesilmesi gerektiğini bilme davranışları ile okul öncesi eğitime başlama yaşı arasında istatiksel olarak anlamlı fark bulunmuştur. Bu fark okul öncesi eğitime 3-4 yaşında başlayanların lehinedir. Bu sonuçlara göre okul öncesi eğitime 3-4 yaşında başlayan çocukların, okul öncesi eğitime 5-6 yaşında başlayan çocuklara göre temizlik ile ilgili öz bakım becerilerinde daha başarılı oldukları söylenebilir. 
Tablo 8. Okul Öncesi Eğitime 5-6 Yaşında Başlayan Çocuklar ile 3-4 Yaşında Başlayan Çocukların Tertip ve Düzen ile İlgili Öz Bakım Becerilerini Kazanım Durumları

\begin{tabular}{|c|c|c|c|c|c|c|c|c|c|c|c|}
\hline $\begin{array}{c}\text { OKUL ÖNCESİ EĞİTİME } \\
\text { BAŞLAMA YAŞI }\end{array}$ & \multicolumn{5}{|c|}{$\begin{array}{c}\text { 5-6 YAŞINDA } \\
\text { BAŞLAYANLAR }\end{array}$} & \multicolumn{5}{|c|}{$\begin{array}{c}\text { 3-4 YAŞINDA } \\
\text { BAŞLAYANLAR }\end{array}$} & $\mathbf{P}$ \\
\hline BECERİ DURUMU & 1 & 2 & 3 & 4 & 5 & 1 & 2 & 3 & 4 & 5 & \\
\hline $\begin{array}{c}\text { TERTİP DÜZEN } \\
\text { ALIŞKANLIĞI İLE İLGÍLI } \\
\text { BECERÍLER }\end{array}$ & $\%$ & $\%$ & $\%$ & $\%$ & $\%$ & $\%$ & $\%$ & $\%$ & $\%$ & $\%$ & \\
\hline $\begin{array}{l}\text { Giysilerini çıardıktan sonra } \\
\text { katlar ve yerine yerleştirir. }\end{array}$ & 9 & 11 & 19 & 34 & 27 & 6 & 13 & 22 & 31 & 28 & $\begin{array}{l}0,672^{*} \\
p>0,05\end{array}$ \\
\hline $\begin{array}{l}\text { Boynuna uygun bir askıya } \\
\text { ceketini veya montunu asar. }\end{array}$ & 10 & 8 & 19 & 35 & 29 & 4 & 8 & 10 & 34 & 44 & $\begin{array}{l}0,036^{* *} \\
P<0,05\end{array}$ \\
\hline Kalktığında yatağını düzenler. & 11 & 14 & 25 & 28 & 22 & 8 & 12 & 30 & 22 & 28 & $\begin{array}{l}0,790^{*} \\
p>0,05\end{array}$ \\
\hline Kendine ait eşyaları toplar. & 5 & 7 & 15 & 28 & 45 & 2 & 5 & 12 & 27 & 54 & $\begin{array}{l}0,299^{*} \\
P<0,5\end{array}$ \\
\hline $\begin{array}{l}\text { Günlük ev işlerinden birini } \\
\text { üstenir. }\end{array}$ & 5 & 11 & 17 & 33 & 33 & 1 & 9 & 28 & 27 & 35 & $\begin{array}{l}0,322^{*} \\
P<0,5\end{array}$ \\
\hline $\begin{array}{l}\text { Haftalık ev işlerinde birini } \\
\text { üstlenir. }\end{array}$ & 7 & 16 & 11 & 35 & 32 & 1 & 7 & 30 & 26 & 36 & $\begin{array}{l}0,014^{* *} \\
P<0,05\end{array}$ \\
\hline
\end{tabular}

Çocukların tertip düzen ile ilgili öz bakım becerilerini okul öncesi eğitime başlama yaşına göre gösteren Tablo 4.7.'de; tertip düzen ile ilgili öz bakım becerilerinden sadece boynuna uygun bir askıya ceketini veya montunu asma, haftalık ev işlerinde birini üstlenme davranışları ile okul öncesi eğitime başlama yaşı arasında istatiksel olarak anlamlı fark 
bulunmuştur. Bu fark okul öncesi eğitime 3-4 yaşında başlayanların lehinedir. Fakat genel olarak tertip düzen ile ilgili becerileri yapmada istatiksel olarak anlamlı bir fark bulunamamıştır. Bu sonuçlara göre okul öncesi eğitime 3-4 yaşında başlayan çocukların, okul öncesi eğitime 5-6 yaşlarında başlayan çocuklara göre tertip düzen ile ilgili öz bakım becerilerinde anlamlı bir farklılığın olmadığı söylenebilir.

Tablo 9. Genel Öz Yeterlilik ve Alt Boyutlardaki Ortalama ve Standart Sapma Değerleri

\begin{tabular}{|c|c|c|c|c|c|c|c|}
\hline & $\begin{array}{c}\text { Okul Öncesi Eğitime } \\
\text { Başlama Yaşı }\end{array}$ & $\mathrm{N}$ & $\begin{array}{c}\text { Ortalam } \\
\text { a }\end{array}$ & $\begin{array}{c}\text { St. } \\
\text { Sapma }\end{array}$ & $\begin{array}{l}\text { St. } \\
\text { Hata } \\
\text { Ort. }\end{array}$ & $\mathrm{T}$ & $\mathrm{P}$ \\
\hline \multirow{2}{*}{ Beslenme } & $\begin{array}{l}\text { 5-6 yaşında } \\
\text { başlayanlar }\end{array}$ & 153 & 3.8712 & .80063 & .06473 & \multirow{2}{*}{-3.589} & \multirow{2}{*}{.000} \\
\hline & $\begin{array}{l}\text { 3-4 yaşında } \\
\text { başlayanlar }\end{array}$ & 100 & 4.1830 & .57946 & .05795 & & \\
\hline \multirow{2}{*}{$\begin{array}{c}\text { Kaza ve } \\
\text { Tehlikelerden } \\
\text { Korunma }\end{array}$} & $\begin{array}{l}\text { 5-6 yaşında } \\
\text { başlayanlar }\end{array}$ & 153 & 3.2135 & .91236 & .07376 & \multirow{2}{*}{-5.012} & \multirow{2}{*}{.000} \\
\hline & $\begin{array}{l}\text { 3-4 yaşında } \\
\text { başlayanlar }\end{array}$ & 100 & 3.7550 & .78940 & .07894 & & \\
\hline \multirow{2}{*}{ Tuvalet } & $\begin{array}{l}\text { 5-6 yaşında } \\
\text { başlayanlar }\end{array}$ & 153 & 4.4323 & .83845 & .06778 & \multirow{2}{*}{-2.344} & \multirow{2}{*}{.020} \\
\hline & $\begin{array}{l}\text { 3-4 yaşında } \\
\text { başlayanlar }\end{array}$ & 100 & 4.6229 & .44879 & .04488 & & \\
\hline \multirow{2}{*}{$\begin{array}{l}\text { Giyinme } \\
\text { Soyunma }\end{array}$} & $\begin{array}{l}\text { 5-6 yaşında } \\
\text { başlayanlar }\end{array}$ & 153 & 3.8214 & .96505 & .07802 & \multirow{2}{*}{-2.345} & \multirow{2}{*}{.020} \\
\hline & $\begin{array}{l}\text { 3-4 yaşında } \\
\text { başlayanlar }\end{array}$ & 100 & 4.0800 & .77975 & .07798 & & \\
\hline
\end{tabular}




\begin{tabular}{|c|c|c|c|c|c|c|c|}
\hline \multirow{2}{*}{ Temizlik } & $\begin{array}{l}\text { 5-6 yaşında } \\
\text { başlayanlar }\end{array}$ & 153 & 3.7366 & .98400 & .07955 & \multirow{2}{*}{-2.847} & \multirow{2}{*}{.005} \\
\hline & $\begin{array}{l}\text { 3-4 yaşında } \\
\text { başlayanlar }\end{array}$ & 100 & 4.0370 & .69292 & .06929 & & \\
\hline \multirow{2}{*}{$\begin{array}{l}\text { Tertip } \\
\text { Düzen }\end{array}$} & $\begin{array}{l}\text { 5-6 yaşında } \\
\text { başlayanlar }\end{array}$ & 153 & 3.6797 & .99533 & .08047 & \multirow{2}{*}{-1.593} & \multirow{2}{*}{.113} \\
\hline & $\begin{array}{l}\text { 3-4 yaşında } \\
\text { başlayanlar }\end{array}$ & 100 & 3.8650 & .83977 & .08398 & & \\
\hline \multirow{2}{*}{$\begin{array}{l}\text { Genel Öz } \\
\text { Yeterlilik }\end{array}$} & $\begin{array}{ll}\text { 5-6 yaşında } \\
\text { başlayanlar }\end{array}$ & 153 & 3.8087 & .76817 & & & \\
\hline & $\begin{array}{ll}3-4 & \text { yaşında } \\
\text { başlayanlar } & \end{array}$ & 100 & 4.1058 & .54517 & & & \\
\hline
\end{tabular}

Okul öncesi eğitime 5-6 yaşında başlayan öğrencilerin yemek yeme ile ilgili davranışlarının ortalaması 3.87 / 5.00' dir (N=153).

Okul öncesi eğitime 3-4 yaşında başlayan öğrencilerin yemek yeme ile ilgili davranışlarının ortalaması 4.18 / 5.00'dir ( $\mathrm{N}=100)$.

Okul öncesi eğitime 5-6 yaşında başlayan öğrencilerin kendini tehlikelerden korunma ile ilgili davranışlarının ortalaması 3.21 / 5.00'dir $(\mathrm{N}=153)$.

Okul öncesi eğitime 3-4 yaşında başlayan öğrencilerin kendini tehlikelerden korunma ile ilgili becerilerinin ortalaması 3.75 / 5.00'dir $(\mathrm{N}=100)$.

Okul öncesi eğitime 5-6 yaşında başlayan öğrencilerin tuvalet alışkanlığ ile ilgili becerilerinin ortalaması 4.43 / 5.00'dir (N=153).

Okul öncesi eğitime 3-4 yaşında başlayan öğrencilerin tuvalet alışkanlığ ile ilgili becerilerinin ortalaması 4.62 / 5.00' dir (N=100).

Okul öncesi eğitime 5-6 yaşında başlayan öğrencilerin giyinme soyunma ile ilgili becerilerinin ortalamas1 $3.82 / 5.00^{\prime}$ dir ( $N=153$ ).

Okul öncesi eğitime 3-4 yaşında başlayan öğrencilerin giyinme soyunma ile ilgili becerilerinin ortalaması 4.08 / 5.00' dir ( $N=100)$. 
Okul öncesi eğitime 5-6 yaşında başlayan öğrencilerin temizlik ile ilgili becerilerinin ortalamas1 $3.73 / 5.00$ ' dir ( $\mathrm{N}=153)$.

Okul öncesi eğitime 3-4 yaşında başlayan öğrencilerin temizlik ile ilgili becerilerinin ortalaması 4.03 / 5.00' dir ( $\mathrm{N}=100)$.

Okul öncesi eğitime 5-6 yaşında başlayan öğrencilerin tertip düzen ile ilgili becerilerinin ortalaması 3.67 / 5.00' dir ( $\mathrm{N}=153)$.

Okul öncesi eğitime 3-4 yaşında başlayan öğrencilerin tertip düzen ile ilgili becerilerinin ortalaması 3.86 / 5.00' dir ( $\mathrm{N}=100)$.

Okul öncesi eğitime 5-6 yaşında başlayan öğrencilerin genel öz yeterlilik düzeylerinin ortalaması 3.80 / 5.00' dir (N=153).

Okul öncesi eğitime 3-4 yaşında başlayan öğrencilerin genel öz yeterlilik düzeylerinin ortalaması 4.10 / 5.00' dir $(\mathrm{N}=100)$

\section{BÖLÜM: TARTIŞMA VE YORUM}

Bu bölümde okul öncesi eğitime 5-6 yaşında başlayan çocuklar ile 34 yaşında başlayan çocukların öz bakım becerilerine ilişkin bulguları tartışılmıştır.

Araştırma ile ilgili bulguların tartışılması ve yorumlanması araştırma sorularının sıralamasına uygun olarak yapılmıştır.

\subsection{Okul Öncesi Eğitime 5-6 Yaşında Başlayan Çocuklar İle 3-4 Yaşında Başlayan Çocukların Yemek Yeme İle İlgili Öz Bakım Becerilerinde Aralarında Anlamlı Bir Farklılık Var mıdır?}

Araştırmanın bu konudaki denencesinde okul öncesi eğitime 5-6 yaşında başlayan ve 3-4 yaşlarında başlayan çocukların beslenme ile ilgili öz bakım beceri düzeyleri arasında bir fark olduğu ileri sürülmüştü. Araştırma bulgularına bakıldığında, okul öncesi eğitime 5-6 yaşında başlayan ve 3-4 yaşında başlayan çocukların beslenme ile ilgili öz bakım beceri düzeyleri arasında anlamlı bir farklılık olduğu bulunmuştur (Bkz. Tablo 4.1.). Bu durumda, "okul öncesi eğitime 5-6 yaşında başlayan ve 3-4 yaşında başlayan öğrencilerin beslenme ile ilgili öz bakım beceri düzeyleri arasında fark vardır" şeklinde kurulan denencenin doğrulandığı sonucuna ulaşılmıştır.

Demiriz ve Dinçer (2000), okul öncesi dönem çocuklarının öz bakım becerilerinin annelerinin çalışıp çalışmama durumlarına göre inceledikleri araştırmada çalışan anne çocuklarının yemek yeme ile ilgili bazı öz bakım becerilerinde daha başarılı oldukları sonucuna ulaşmışlardır. Aynı çalışmada çok küçük yaşlardan itibaren çocukların kendi yiyeceklerini kendilerinin seçmeleri, hazırlamaları gibi etkinliklerin, çocukların yemek 
yeme ile ilgili iyi alışkanlıklar kazanmalarını sağlamanın yanı sıra onların öz güvenlerini geliştirerek tüm gelişimlerini de destekleyeceği de belirtilmiştir.

Küçükali (2010), çocuklarda beslenme bozuklukları ve beslenmenin okul çocukları üzerindeki etkileri konusunda yaptığı araştırmasında anaokuluna gittikten sonra ilköğretime başlamış öğrencilerin, anaokuluna gitmeden ilköğretime başlamış öğrencilere göre beslenmelerine daha dikkat ettikleri sonucuna varmıştır.

Güneyli (1988), 4-6 yaş grubu çocuklarında beslenme alışkanlıkları ve bunu etkileyen etmenler konusunda yaptığı araştırmasında, ailelerin çocuklarına iyi beslenme alışkanlıkları kazandırmak için gayret sarf ettiklerini ve sofrada çocukla ilgilenilmesi, besinlerin ödül aracı olarak kullanılmaması vb. gibi olumlu davranışlar içinde olduklarını gözlediğini belirtmektedir.

Demiriz ve Dinçer (2001), 5-6 yaş çocuklarının öz bakım becerilerinin cinsiyet ve okul öncesi eğitim alma durumlarına göre inceledikleri araştırmada okul öncesi eğitim almayan çocukların yemek yeme ile ilgili öz bakım becerilerinde daha çok zorlandıkları, okul öncesi eğitim alma süresi artıkça bu davranışları daha rahat yapabildikleri sonucuna varmışlardır.

Shannon ve Chen (1988), 3 yll süren beslenme eğitimiyle ilgili yaptıkları çalışmalarda, deney grubundaki çocuklara 3, 4, ve 5 yaşlarında, başlangiçta belirlenen beslenme bilgisi, kendi kendine yemek yeme davranışları konusunda her yıl 9-12 haftalık eğitim vermişlerdir. Uygulama sonrası eğitim alan çocukların kontrol grubundaki çocuklara göre daha yüksek puanlar aldıklarını saptamışlardır.

Konya (2007), kubaşık öğrenme etkinliklerinin beş yaş grubu çocukların öz bakım becerilerinin gelişimine etkisini araştırdığı çalışmasında kubaşık öğrenme etkinliklerinin uygulandığı deney grubu ile çoklu zeka etkinliklerinin uygulandığı kontrol grubunun öz bakım becerileri kontrol listesi "yemek yeme becerileri" son test puanlarından ön test puanları çıkarılarak elde edilen erişi puanları arasında bir beceri dışında (yemek yerken kaşığı tutma) diğer beceriler açısından deney grubu lehine anlamlı farklar olduğu sonucuna varmıştır.

Okul öncesi eğitim alma ve öz bakım becerileri değişkenlerinin incelendiği araştırmaların sonuçları göstermektedir ki okul öncesi eğitim, öz bakım becerilerinden biri olan beslenme becerilerinin gelişimini olumlu yönde etkilemekte ve araştırmanın sonucunu desteklemektedir.

Öz bakım becerileri doğuştan getirilmeyip, öğrenilerek kazanılan becerilerdir. Öz bakım becerilerinden olan yemek yeme becerisinin de her 
yaş döneminde kazanılması gereken farklı becerileri vardır. İlk yaşlarda kazanılmayan bir beceri diğer yaşlardaki becerilerin gelişimini de etkileyeceği için okul öncesi eğitime ne kadar erken başlanırsa yemek yeme becerisi ile ilgili davranışlarda sırası ile kazandırılacaktır.

\subsection{Okul Öncesi Eğitime 5-6 Yaşında Başlayan Çocuklar İle 3-4 Yaşında Başlayan Çocukların Kazalardan ve Tehlikelerden Korunma İle İlgili Öz Bakım Becerilerinde Aralarında Anlamlı Bir Farklılık Var mıdır?}

Araştırmanın bu konudaki denencesinde okul öncesi eğitime 5-6 yaşında başlayan ve 3-4 yaşlarında başlayan çocukların kazalardan ve tehlikelerden korunma ile ilgili öz bakım beceri düzeyleri arasında bir fark olduğu ileri sürülmüştü. Araştırma bulgularına bakıldığında, okul öncesi eğitime 5-6 yaşında başlayan ve 3-4 yaşında başlayan öğrencilerin kazalardan ve tehlikelerden korunma ile ilgili öz bakım beceri düzeyleri arasında anlamlı bir farklılık bulunmuştur (Bkz. Tablo 4.1.). Bu durumda, "okul öncesi eğitime 5-6 yaşında başlayan ve 3-4 yaşında başlayan çocukların kazalardan ve tehlikelerden korunma ile ilgili öz bakım beceri düzeyleri arasında fark vardır" şeklinde kurulan denencenin doğrulandığ 1 sonucuna ulaşılmıştır.

Postacı (1992), çocukluk çağı kazalarını incelemek amacıyla yaptığı araştırmada 3-4 yaşlarda lökomosyon ve beceriler arttıkça kaza oranında ona göre bir artış olduğunu, 5. ve 6. yaşlarında ise tekrar çevreye uyma yeteneklerinin (algisal, bilişsel, motor beceriler) gelişimi bir etmen olarak kaza oranını düşürdügünü belirtmiştir. Olguların yaşa göre dağılımını incelediğinde ise kazaların \%33.3'ünün 1-4 yaş grubunda, \%30.9'unun 5-9 yaş grubunda olduğunu gözlemlemiştir. 1-4 yaş grubunun çevreyi keşfetme isteği ve bu yönde hareketliliğinin artması kaza oranını arttırıcı neden olarak düşünülebileceğini belirtmiştir.

Demiriz ve Dinçer (2000), yaptıkları araştırmada tüm zararlı şeylerden (sivri uçlu, kesici, yanıcı, zehirli madde vb.) kendini koruma, arabada arka koltukta oturma, arabada emniyet kemerini takma davranışları ile annenin çalışıp-çalışmama durumu arasında istatistiksel olarak anlamlı fark bulmuştur. Bu fark çalışan anne çocuklarının lehinedir.

Yapılan az sayıdaki davranışsal çalışmada ülkemizde ailelerin kazalardan korunma bilgisi yetersiz olup çocukların kaza geçirme riski yüksek bulunmuştur. Kaza /yaralanma riski kırsal ve yarı-kentsel yerleşim bölgelerinde, öğrenim düzeyinin, sosyo-ekonomik düzeyin düşük olduğu ailelerde, kalabalık ailelerde artmaktadır.

Kazalardan ve tehlikelerden korunma becerisi çocuk kendi başına hareket etmeye başladığından itibaren oluşmaya başlamaktadır. Okul öncesi 
dönemde çocuk, devamlı hareket halindedir ve çevreyi tanımaya çalışmaktadır. Bu dönemde kendisini bazen tehlikeli durumlar içinde bulabilir. Çocuğun çevresindeki olayları daha yakından tanıma çabası, kendi gücünün sınırlarını öğrenebilmek için kendini tehlikeli durumlara sokacaktır. Çocuğun tehlikelerle karşılaştığı bu dönemdeki kazalar bazen tüm hayatını etkileyebilecek sonuçlara sebep olabilir. Tehlikelere karşı korunmayı ilk olarak evde öğrenen çocuk, verilecek olan kaliteli bir okul öncesi eğitimle de tehlikeli ve zararlı olan durumları öğrenecek ve kendini tehlikelerden koruyabilecek becerileri edinecektir.

5.3. Okul Öncesi Eğitime 5-6 Yaşında Başlayan Çocuklar İle 3-4 Yaşında Başlayan Çocukların Tuvalet Alışkanlığı İle İlgili Öz Bakım Becerilerinde Aralarında Anlamlı Bir Farklılık Var mıdır?

Araştırmanın bu konudaki denencesinde okul öncesi eğitime 5-6 yaşında başlayan ve 3-4 yaşında başlayan çocukların tuvalet alışkanlığı ile ilgili öz bakım beceri düzeyleri arasında bir fark olduğu ileri sürülmüştü. Araştırma bulgularına bakıldığında, okul öncesi eğitime 5-6 yaşında başlayan ve 3-4 yaşında başlayan çocukların tuvalet alışkanlığı ile ilgili öz bakım beceri düzeyleri arasında anlamlı bir farklılık olduğu bulunmuştur. Bu durumda, "okul öncesi eğitime 5-6 yaşında başlayan ve 3-4 yaşlarında başlayan çocukların tuvalet alışkanlığı ile ilgili öz bakım beceri düzeyleri arasında fark vardır" şeklinde kurulan denencenin doğrulandığı sonucuna ulaşılmıştır.

Demiriz ve Dinçer (2000), yaptıkları araştırmada, zamanında tuvalete gitme ve giysilerini indirme tuvalet ihtiyacını giderme, tuvalet kağıdı kullanarak yardımsız temizlenme, sifonu çekme, tuvaletten sonra ellerini sabun ile yikama tuvaleti geldiğinde uykusundan uyanma veya bütün gece altı kuru kalma davranışları ile annenin çalışma durumu arasında anlamlı fark bulmuştur. Sonuçlara göre çalışan anne çocuklarının tuvalet ile ilgili öz bakım becerilerini daha iyi yaptıkları gözlenmiştir.

Demiriz ve Dinçer (2001), yaptıkları araştırmada, tuvalet alışkanlığı ile ilgili öz bakım becerilerinin hemen hemen tümünün kazanılmasında, okulöncesi eğitimin önemli bir faktör olduğu ve okul öncesi eğitim alma süresi artıkça tuvalet alışkanlığı ile ilgili öz bakım becerilerinde çocukların daha başarılı olduklarını belirtmişlerdir.

Bir çocuğun hayatındaki en önemli dönemlerden biri tuvalet eğitimini kazandığı dönemdir. Tuvalet eğitimi, çocuğun kimsenin yardımı olmadan, kendi kendine tuvaletinin geldiğinin farkına varıp, tuvalet ihtiyacını giderebilmesidir. Çoğu çocuk, 3-4 yaş dolayında barsak kontrolü ve gündüz idrar kontrolünü başarır. Geceleri kuru kalmak içinse, bazen birkaç ay hatta 
yıla gerek duyabilir. Tuvalet alışkanlığını kazandıktan sonra, 4-5 yaşlarında, temizlik alışkanlığını da çocuğa kazandırmak gerekir. Kısaca tuvaletini yaptıktan sonra hem kendi temizliğini hem de tuvaletin temizliğinin nasıl olacağını kazanmış olmalıdır. Okul öncesi eğitimin erken yaşta alınması da çocuğun evden farklı bir yerde ailesinin kontrolü olmadan bu ihtiyacını gidermesini gerektirecektir. Çocuk tuvalet alışkanlığı ile ilgili becerileri öncesi ve sonrasında yapılması gerekenleri öğrenecek ve pekiştirecektir.

5.4. Okul Öncesi Eğitime 5-6 Yaşında Başlayan Çocuklar İle 3-4 Yaşında Başlayan Çocukların Giyinme Soyunma İle İlgili Öz Bakım Becerilerinde Aralarında Anlamlı Bir Farklılık Var mıdır?

Araştırmanın bu konudaki denencesinde okul öncesi eğitime 5-6 yaşında başlayan ve 3-4 yaşında başlayan çocukların giyinme soyunma ile ilgili öz bakım beceri düzeyleri arasında bir fark olduğu ileri sürülmüştü. Araştırma bulgularına bakıldığında, okul öncesi eğitime 5-6 yaşında başlayan ve 3-4 yaşında başlayan çocukların giyinme soyunma ile ilgili öz bakım beceri düzeyleri arasında anlamlı bir farklılık bulunmuştur (Bkz. Tablo 4.1.). Bu durumda, "okul öncesi eğitime 5-6 yaşında başlayan ve 3-4 yaşında başlayan çocukların giyinme soyunma ile ilgili öz bakım beceri düzeyleri arasında fark vardır" şeklinde kurulan denencenin doğrulandığ sonucuna ulaşılmıştır.

Demiriz ve Dinçer (2000), yaptıkları araştırmada çocukların giyinme-soyunma ile ilgili öz bakım becerilerini annelerinin çalışıpçalışmama durumuna göre incelemiş ve çalışan annelerin çocuklarının giyinme-soyunma ile ilgili öz bakım becerilerinde çalışmayan annelerin çocuklarına göre daha başarılı oldukları sonucuna ulaşmışlardır.

Demiriz ve Dinçer (2001), yaptıkları araştırmada bazı giyinme soyunma davranışları ile okul öncesi eğitim alma durumları arasında istatistiksel olarak anlamlı fark bulmuşlardır. Ayakkabılarını yardımsız bağlama ve duruma ve hava şartlarına uygun giyecekleri seçme davranışları ile okul öncesi eğitim alma süreleri arasındaki anlamlı farkın, okul öncesi eğitimi iki yıldan fazla alan gruptan kaynaklandığı saptanmıştır. Bu sonuç kuruma giden çocukların söz konusu davranışları her gün tekrarlamalarına bağlı olarak bu davranışlar üzerinde daha iyi beceri kazanmaları ile açıklanmıştır.

Çocuğun kazanması gereken öz bakım becerilerinden biri olan giyinme, beceri isteyen bir takım davranışların birbiri ardına yapılmasını gerektirir. Diğer bütün becerilerde olduğu gibi öz bakım becerilerinin öğretimi de zamanında yapılmalıdır. Bu anlamda ne kadar erken harekete geçilirse, çocuğun becerileri ögrenme düzeyi ona paralel olarak yükselir. 
Okul öncesi eğitime erken yaşta başlayan çocuklar her gün rutin olarak bu becerileri (ayakkabısının giyip çıkarma, dış kıyafetini çıkarıp asma vb.) tekrar ettiklerinden becerileri öğrenmeleri de daha erken olacaktır.

\subsection{Okul Öncesi Eğitime 5-6 Yaşında Başlayan Çocuklar İle 3-4 Yaşında Başlayan Çocukların Temizlik İle İlgili Öz Bakım Becerilerinde Aralarında Anlamlı Bir Farklılık Var Mıdır?}

Araştırmanın bu konudaki denencesinde okul öncesi eğitime 5-6 yaşında başlayan ve 3-4 yaşında başlayan çocukların temizlik ile ilgili öz bakım beceri düzeyleri arasında bir fark olduğu ileri sürülmüştü. Araştırma bulgularına bakıldığında, okul öncesi eğitime 5-6 yaşında başlayan ve 3-4 yaşında başlayan çocukların temizlik ile ilgili öz bakım beceri düzeyleri arasında anlamlı bir farklılık bulunmuştur (Bkz. Tablo 4.1.). Bu durumda, "okul öncesi eğitime 5-6 yaşında başlayan ve 3-4 yaşında başlayan çocukların temizlik ile ilgili öz bakım beceri düzeyleri arasında fark vardır" şeklinde kurulan denencenin doğrulandığı sonucuna ulaşılmıştır.

Demiriz ve Dinçer (2000), yaptıkları çalışmada çocukların temizlik ile ilgili öz bakım becerilerinin annelerinin çalışıp çalışmama durumuna göre incelemiş çalışan anne çocuklarının temizlikle ilgili öz bakım becerileri konusunda daha başarılı oldukları sonucuna ulaşmışlardır.

Demiriz ve Dinçer (2001), 5-6 yaş çocuklarının öz bakım becerilerinin cinsiyet ve okul öncesi eğitim alma durumlarına göre inceledikleri araştırmada, temizlikle ilgili öz bakım becerilerinin okul öncesi eğitimi alan çocukların lehine sonuçlara ulaşılmıştır. Aynı becerileri cinsiyete göre incelediklerinde ise sonuçlar kız çocuklarının lehine çıkmıştır. $\mathrm{Bu}$ durumu ise kız çocukların erkek çocuklara göre temizlik kurallarına daha çok uymaları ve kendi bakımlarıyla daha çok ilgilenmelerine bağlamışlardır.

Gazezoğlu (2007), okul öncesi eğitimine devam eden 6 yaş grubu çocuklarına öz bakım becerilerinin oyun yoluyla kazandırılmasını incelediği araştırmasında, öz bakım becerilerinden olan temizlik becerisinin kazandırılmasında oyun ile öğretimin geleneksel öğretimden daha etkili olduğunu belirtmiştir.

Temizlik alışkanlığı da diğer temel beceriler gibi çocukta 2-3 yaşında hızla gelişmeye başlamaktadır. Anne, baba veya eğitimci tarafından çoğu zaman bizzat yapılarak öğretilen temizlik uygulamalarının, 2-3 yaşından itibaren çocuğun kendisinin yapılabilmesi için gerekli ortamların hazırlanması gerekmektedir. Okul öncesi eğitim kurumlarında temizlik ile ilgili becerileri çocuklar kendileri bizzat yaparak öğrenirler. Örneğin 
kahvaltı etkinliklerinden önce ve sonra el yıkama, beslenmeden sonra diş fırçalama gibi beceriler aşamalı olarak ve sürekli bir şekilde öğretilmektedir.

\subsection{Okul Öncesi Eğitime 5-6 Yaşında Başlayan Çocuklar İle 3-4 Yaşında Başlayan Çocukların Tertip Düzen İle İlgili Öz Bakım Becerilerinde Aralarında Anlamlı Bir Farklılık Var Mıdır?}

Araştırmanın bu konudaki denencesinde okul öncesi eğitime 5-6 yaşında başlayan ve 3-4 yaşında başlayan çocukların tertip düzen ile ilgili öz bakım beceri düzeyleri arasında bir fark olduğu ileri sürülmüştü. Araştırma bulgularına bakıldığında, okul öncesi eğitime 5-6 yaşında başlayan ve 3-4 yaşında başlayan çocukların tertip düzen ile ilgili öz bakım beceri düzeyleri arasında anlamlı bir farklılık bulunmamıştır (Bkz. Tablo 4.1.). Bu durumda, "okul öncesi eğitime 5-6 yaşında başlayan ve 3-4 yaşında başlayan çocukların tertip düzen ile ilgili öz bakım beceri düzeyleri arasında fark vardır" şeklinde kurulan denencenin doğrulanmadığı sonucuna ulaşılmıştır.

Demiriz ve Dinçer (2000), yaptıkları çalışmada çocukların tertip düzen ile ilgili öz bakım becerilerinin annelerinin çalışıp çalışmama durumuna göre incelemiş çalışan anne çocuklarının tertip düzen ile ilgili öz bakım becerilerinden giyeceklerini çıkardıktan sonra yerine yerleştirme davranışı ile pijamalarını katlama davranışında daha başarılı olduklarını belirtmişlerdir.

Demiriz ve Dinçer (2001), 5-6 yaş çocuklarının öz bakım becerilerinin cinsiyet ve okul öncesi eğitim alma durumlarına göre inceledikleri araştırmada okul öncesi eğitim yaşantısının, çocukların sınıfı toplama, oyuncakları yerleştirme vb. çocukların tertip-düzen ile ilgili öz bakım becerilerinin kazanmalarını olumlu yönde etkilediğini belirtmişlerdir.

5.7. Okul Öncesi Eğitime 5-6 Yaşında Başlayan Çocuklar İle 3-4 Yaşında Başlayan Çocukların Genel Öz Yeterlilik İle İlgili Becerilerinde Aralarında Anlamlı Bir Farklılık Var Mıdır?

Araştırmanın bu konudaki denencesinde okul öncesi eğitime 5-6 yaşında başlayan ve 3-4 yaşında başlayan çocukların genel öz yeterlilik ile ilgili öz bakım beceri düzeyleri arasında bir fark olduğu ileri sürülmüştü. Araştırma bulgularına bakıldığında, okul öncesi eğitime 5-6 yaşında başlayan ve 3-4 yaşında başlayan çocukların genel öz yeterlilik ile ilgili öz bakım beceri düzeyleri arasında bir fark olduğu görülmektedir. $\mathrm{Bu}$ durumda, "okul öncesi eğitime 5-6 yaşında başlayan ve 3-4 yaşında başlayan öğrencilerin genel öz yeterlilik ile ilgili öz bakım beceri düzeyleri arasında fark vardır" şeklinde kurulan denencenin doğrulandığı sonucuna ulaşılmıştır. 


\section{SONUÇ VE ÖNERILER}

Araştırmanın bu bölümünde araştırma sonucunda elde edilen bulgulara dayalı genel sonuç ve önerilere yer verilmiştir.

Araştırmada okul öncesi eğitime 5-6 yaşında başlayan çocuklar ile daha erken yaşta başlayan çocukların öz bakım becerileri arasında anlamlı bir farklılığın olup olmadığı araştırılmıştır.

Okul Öncesi Eğitime 5-6 Yaşında Başlayan Çocuklar İle 3-4 Yaşında Başlayan Çocukların Yemek Yeme İle İlgili Öz Bakım Beceri Düzeyleri Arasındaki Farka Yönelik Sonuçlar:

Okul öncesi eğitime 5-6 yaşında başlayan çocuklar ile 3-4 yaşında başlayan çocukların beslenme ile ilgili öz bakım beceri düzeyleri arasında istatistiksel bakımdan anlamlı bir farklılık olduğu sonucuna ulaşılmıştır.

Araştırmada, okul öncesi eğitime 3-4 yaşında başlayan çocukların beslenme ile ilgili öz bakım beceri düzeylerinin, okul öncesi eğitime 5-6 yaşında başlayan çocukların beslenme ile ilgili öz bakım beceri düzeylerinden daha gelişmiş olduğu sonucuna ulaşılmıştır.

Araştırmada, okul öncesi eğitime 3-4 yaşında başlayan çocukların yemekte başkasına ait bardak, çatal vb.lerini kullanmama, Bıçak kullanarak yumuşak besinleri kesme, acıktığında kendi için soğuk sandviç hazırlama, yemek istediği yiyecekleri tabağına alma, bardağına dökmeden su, süt veya meyve suyu doldurma, yiyecekleri yerken görgü kurallarına uyma becerilerinin okul öncesi eğitime 5-6 yaşında başlayan çocuklara göre daha gelişmiş olduğu sonucuna ulaşılmıştır.

Araştırma bulguları esas alınarak, okul öncesi eğitime 3-4 yaşında başlayan çocukların beslenme ile ilgili öz bakım beceri düzeylerinin okul öncesi eğitime 5-6 yaşında başlayan çocukların beslenme ile ilgili öz bakım beceri düzeylerinden daha gelişmiş olduğu, çocukların beslenme ile ilgili öz bakım beceri düzeylerinin okul öncesi eğitime başlama yaşı ile ilişkili olduğu söylenebilir.

Okul Öncesi Eğitime 5-6 Yaşında Başlayan Çocuklar İle 3-4 Yaşında Başlayan Çocukların Kazalardan ve Tehlikelerden Korunma İle İlgili Öz Bakım Beceri Düzeyleri Arasındaki Farka Yönelik Sonuçlar: 
Okul öncesi eğitime 5-6 yaşında başlayan çocuklar ile 3-4 yaşında başlayan çocukların kazalardan ve tehlikelerden korunma ile ilgili öz bakım beceri düzeyleri arasında istatistiksel bakımdan anlamlı bir farklılık olduğu sonucuna ulaşılmıştır.

Araştırmada, okul öncesi eğitime 3-4 yaşında başlayan çocukların kazalardan ve tehlikelerden korunma ile ilgili öz bakım beceri düzeylerinin, okul öncesi eğitime 5-6 yaşında başlayan çocukların kazalardan ve tehlikelerden korunma ile ilgili öz bakım beceri düzeylerinden daha gelişmiş olduğu sonucuna ulaşılmıştır.

Araştırmada, okul öncesi eğitime 3-4 yaşında başlayan çocukların, evinin yakınlarında sürekli yetişkin denetimi olmadan dolaşabilme, tehlikeli eşyalardan kendini koruma, araçta emniyet kemerini kullanma becerilerinin okul öncesi eğitime 5-6 yaşında başlayan çocuklardan daha gelişmiş olduğu sonucuna ulaşılmıştır.

Araştırma bulguları esas alınarak, okul öncesi eğitime 3-4 yaşında başlayan çocukların kazalardan ve tehlikelerden korunma ile ilgili öz bakım beceri düzeylerinin okul öncesi eğitime 5-6 yaşında başlayan çocukların kazalardan ve tehlikelerden korunma ile ilgili öz bakım beceri düzeylerinden daha gelişmiş olduğu, çocukların kazalardan ve tehlikelerden korunma ile ilgili öz bakım beceri düzeylerinin okul öncesi eğitime başlama yaşı ile ilişkili olduğu söylenebilir.

Okul Öncesi Eğitime 5-6 Yaşında Başlayan Çocuklar İle 3-4 Yaşında Başlayan Çocukların Tuvalet Alışkanlığı İle İlgili Öz Bakım Beceri Düzeyleri Arasındaki Farka Yönelik Sonuçlar:

Okul öncesi eğitime 5-6 yaşında başlayan çocuklar ile 3-4 yaşında başlayan çocukların tuvalet alışkanlığı ile ilgili öz bakım beceri düzeyleri arasında istatistiksel bakımdan anlamlı bir farklılık olduğu sonucuna ulaşılmıştır.

Araştırmada, okul öncesi eğitime 3-4 yaşında başlayan çocukların tuvalet alışkanlığı ile ilgili öz bakım beceri düzeylerinin, okul öncesi eğitime 5-6 yaşında başlayan çocukların tuvalet alışkanlığı ile ilgili öz bakım beceri düzeylerinden daha gelişmiş olduğu sonucuna ulaşılmıştır.

Araştırmada, okul öncesi eğitime 3-4 yaşında başlayan çocukların, tuvalet ihtiyacının farkında olma ve zamanında gitme, tuvalet ihtiyacını giderdikten sonra tuvalet kâğıdı ve su kullanarak yardımsız temizliğini yapma, tuvalet ihtiyacını giderdikten sonra iç çamaşırını ve pantolonunu uygun şekilde giyme, tuvalet ihtiyacını yapmadan önce ve tuvaletini yaptıktan sonra sifonu çekme ve tuvaleti temiz bırakma, tuvalete gitmesi 
gerektiğinde uykusundan uyanma ve gece altının kuru kalması becerilerinin okul öncesi eğitime 5-6 yaşında başlayan çocuklardan daha gelişmiş olduğu sonucuna ulaşılmıştır.

Araştırma bulguları esas alınarak, okul öncesi eğitime 3-4 yaşında başlayan çocukların tuvalet alışkanlığı ile ilgili öz bakım beceri düzeylerinin okul öncesi eğitime 5-6 yaşında başlayan çocukların tuvalet alışkanlığı ile ilgili öz bakım beceri düzeylerinden daha gelişmiş olduğu, çocukların tuvalet alışkanlığı ile ilgili öz bakım beceri düzeylerinin okul öncesi eğitime başlama yaşı ile ilişkili olduğu söylenebilir.

Okul Öncesi Eğitime 5-6 Yaşında Başlayan Çocuklar İle 3-4 Yaşında Başlayan Çocukların Giyinme Soyunma İle İlgili Öz Bakım Beceri Düzeyleri Arasındaki Farka Yönelik Sonuçlar:

Okul öncesi eğitime 5-6 yaşında başlayan çocuklar ile 3-4 yaşında başlayan çocukların giyinme soyunma ile ilgili öz bakım beceri düzeyleri arasında istatistiksel bakımdan anlamlı bir farklılık olduğu sonucuna ulaşılmıştır.

Araştırmada, okul öncesi eğitime 3-4 yaşında başlayan çocukların giyinme soyunma ile ilgili öz bakım beceri düzeylerinin, okul öncesi eğitime 5-6 yaşında başlayan çocukların giyinme soyunma ile ilgili öz bakım beceri düzeylerinden daha gelişmiş olduğu sonucuna ulaşılmıştır.

Araştırmada, okul öncesi eğitime 3-4 yaşında başlayan çocukların, ayakkabılarını kendi giyme, ayakkabılarının bağcıklarını yardımsız bağlama, duruma ve hava şartlarına uygun giyeceği seçme becerilerinin okul öncesi eğitime 5-6 yaşında başlayan çocuklardan daha gelişmiş olduğu sonucuna ulaşılmıştır.

Araştırma bulguları esas alınarak, okul öncesi eğitime 3-4 yaşında başlayan çocukların giyinme soyunma ile ilgili öz bakım beceri düzeylerinin okul öncesi eğitime 5-6 yaşında başlayan çocukların giyinme soyunma ile ilgili öz bakım beceri düzeylerinden daha gelişmiş olduğu, çocukların giyinme soyunma ile ilgili öz bakım beceri düzeylerinin okul öncesi eğitime başlama yaşı ile ilişkili olduğu söylenebilir.

Okul Öncesi Eğitime 5-6 Yaşında Başlayan Çocuklar İle 3-4 Yaşında Başlayan Çocukların Temizlik İle İlgili Öz Bakım Beceri Düzeyleri Arasındaki Farka Yönelik Sonuçlar: 
Okul öncesi eğitime 5-6 yaşında başlayan öğrenciler ile 3-4 yaşında başlayan öğrencilerin temizlik ile ilgili öz bakım beceri düzeyleri arasında istatistiksel bakımdan anlamlı bir farklılık olduğu sonucuna ulaşılmıştır.

Araştırmada, okul öncesi eğitime 3-4 yaşında başlayan çocukların temizlik ile ilgili öz bakım beceri düzeylerinin, okul öncesi eğitime 5-6 yaşında başlayan çocukların temizlik ile ilgili öz bakım beceri düzeylerinden daha gelişmiş olduğu sonucuna ulaşılmıştır.

Araştırmada, okul öncesi eğitime 3-4 yaşında başlayan çocukların, sabah kalktığında hatırlatılmadan yüzünü yıkama ve havlu ile kurulama, yemekten önce ve sonra hatırlatılmadan ellerini yıkama ve kurulama, dişlerini yardımsız günde en az 2 defa fırçalama, öksürürken ve hapşırırken eliyle ya da mendille ağzını kapatma, sırt, boyun ve ense hariç kendini yıkama, saçlarını yardımsız kurutma, tırnakları uzadığında kesilmesi gerektiğini bilme ve yetişkinden yardım isteme becerilerinin okul öncesi eğitime 5-6 yaşında başlayan çocuklardan daha gelişmiş olduğu sonucuna ulaşılmıştır.

Araştırma bulguları esas alınarak, okul öncesi eğitime 3-4 yaşında başlayan çocukların temizlik ile ilgili öz bakım beceri düzeylerinin okul öncesi eğitime 5-6 yaşında başlayan çocukların temizlik ile ilgili öz bakım beceri düzeylerinden daha gelişmiş olduğu, çocukların temizlik ile ilgili öz bakım beceri düzeylerinin okul öncesi eğitime başlama yaşı ile ilişkili olduğu söylenebilir.

Okul Öncesi Eğitime 5-6 Yaşında Başlayan Çocuklar İle 3-4 Yaşında Başlayan Çocukların Tertip Düzen İle İlgili Öz Bakım Beceri Düzeyleri Arasındaki Farka Yönelik Sonuçlar:

Okul öncesi eğitime 5-6 yaşında başlayan çocuklar ile 3-4 yaşında başlayan çocukların tertip düzen ile ilgili öz bakım beceri düzeyleri arasında istatistiksel bakımdan anlamlı bir farklılık olmadığı sonucuna ulaşılmıştır.

Araştırmada, okul öncesi eğitime 3-4 yaşında başlayan çocukların tertip düzen ile ilgili öz bakım becerilerinden boynuna uygun bir askıya ceketini veya montunu asma, haftalık ev işlerinde birini üstlenme becerilerinin dışında diğer becerilerde okul öncesi eğitime 5-6 yaşında başlayan çocukların tertip düzen ile ilgili öz bakım beceri düzeyleri ile benzerlik gösterdiği sonucuna ulaşılmıştır.

Araştırma bulguları esas alınarak, okul öncesi eğitime 3-4 yaşında başlayan çocukların tertip düzen ile ilgili öz bakım beceri düzeylerinin okul öncesi eğitime 5-6 yaşında başlayan çocukların tertip düzen ile ilgili öz bakım beceri düzeyleri ile aralarında anlamlı bir fark olmadığı, çocukların 
tertip düzen ile ilgili öz bakım beceri düzeylerinin okul öncesi eğitime başlama yaşı ile ilişkili olmadığı söylenebilir.

Okul Öncesi Eğitime 5-6 Yaşında Başlayan Çocuklar İle 3-4 Yaşında Başlayan Çocukların Genel Öz Yeterlilik Düzeyleri Arasındaki Farka Yönelik Sonuçlar:

Okul öncesi eğitime 5-6 yaşında başlayan çocuklar ile 3-4 yaşında başlayan çocukların genel öz yeterlilik düzeyleri arasında istatistiksel bakımdan anlamlı bir farklılık olduğu sonucuna ulaşılmıştır.

Araştırmada, okul öncesi eğitime 3-4 yaşında başlayan çocukların genel öz yeterlilik düzeylerinin, okul öncesi eğitime 5-6 yaşında başlayan öğrencilerin genel öz yeterlilik düzeylerinden daha gelişmiş olduğu sonucuna ulaşılmıştır.

Araştırma bulguları esas alınarak, okul öncesi eğitime 3-4 yaşında başlayan çocukların genel öz yeterlilik düzeylerinin okul öncesi eğitime 5-6 yaşında başlayan çocukların genel öz yeterlilik düzeylerinden daha gelişmiş olduğu, çocukların genel öz yeterlilik düzeylerinin okul öncesi eğitime başlama yaşı ile ilişkili olduğu söylenebilir.

\section{ÖNERILER}

Araştırmanın bulguları ve sonuçları doğrultusunda ailelere, eğitimcilere ve yapılacak olan araştırmalara yönelik çeşitli önerilerde bulunulabilinir.

\subsubsection{Ailelere Yönelik Öneriler}

Araştırma sonucunda, okul öncesi eğitime 3-4 yaşında başlayan çocukların öz bakım beceri düzeylerinin okul öncesi eğitime 5-6 yaşında başlayan çocukların öz bakım beceri düzeylerinden daha gelişmiş olduğu sonucuna ulaşılmıştır. Araştırma sonuçlarına göre, okul öncesi eğitime erken yaşta başlamak çocukların öz bakım beceri düzeylerini olumlu yönde etkilemektedir. $\mathrm{Bu}$ nedenle ailelerin çocuklarını erken yaşta okul öncesi eğitim kurumuna göndermelerinin çocuğun öz bakım beceri gelişimi açısından olumlu olacağı düşünülmekte ve ailelere çocuklarını erken yaşta okul öncesi eğitim kurumuna göndermeleri önerilmektedir.

\subsubsection{Eğitimcilere Yönelik Öneriler}

Okul öncesi eğitim alanında çalışan eğitimcilerin öz bakım becerilerini geliştirici etkinliklere gün içinde yapılacak etkiliklerde de yer vermeleri önerilmektedir. 
Eğitimcilere, okul öncesi eğitimin önemini anlatmak ve okul öncesi eğitime erken yaşlarda başlamayı sağlamak amacıyla okul öncesi eğitimin önemi ve okul öncesi eğitimin uzun vadede sağlayacağı katkılarla ilgili ailelere düzenli olarak seminerler düzenlemeleri önerilmektedir.

\subsubsection{Yapılacak Araştırmalara Yönelik Öneriler}

$\mathrm{Bu}$ çalışmada öz bakım becerilerinden yemek yeme, giyinmesoyunma, tuvalet alışkanlığı, tertip-düzen kaza ve tehlikelerden korunma becerileri ele alınmıştır. Bu becerilerin dışında dinlenme alışkanlığı becerisi de araştırma konusu olabilir.

Çocukların öz bakım becerilerinin gelişimleri ailenin sosyoekonomik düzeyi (alt-orta-üst) anne-baba tutumları, çocuğun cinsiyeti ve kardeş sayısı, kaçıncı çocuk olduğu gibi çeşitli değişkenler açısından ele alınarak çalışmalar yapılabilir.

\section{Kaynakça}

Akar, S. (2006). “Özel ve Resmi Okul Öncesi Eğitim Kurumlarnna Devam Eden Dört -Altı Yaş Grubu Çocuklarının Beslenme Alışkanlıklarının Karşılaştırılması", Gazi Üniversitesi, Eğitim Bilimleri Enstitüsü, Yayınlanmamış Yüksek Lisans Tezi, Ankara.

Akyüz, Y. (1996). Anaokullarının Türkiye'de kuruluş ve gelişim tarihçesi. Millî Ĕ̆itim Dergisi, sayı:132.

Aydın, H.B. ve Aydın, O. (1999). Okul öncesi çocuğunun gelişim özellikleri. Marmara Üniversitesi Anaokulu/Anasınıfı Öğretmeni El Kitabı İstanbul: Remzi Kitabevi.

Aydın, O. (2005). Okul Öncesi Dönem Çocuğunun Gelişim Özellikleri. Erken Çocuklukta Gelişim ve Eğitimde Yeni Yaklaşımlar, Derl.:Müzeyyen Sevinç İstanbul: Morpa Yayınları.

Baltaş, A. (2004). Ana-Baba Okulu (11.Basım). İstanbul: Remzi Kitabevi

Başal, H. A. (2005). Okul öncesi eğitim. İstanbul: Morpa Kültür Yayınları

Başaran, İ.E. (1982). Eğitim psikolojisi. Ankara: Emel Matbaacıllk 
Bayhan, S.P. ve Artan, İ. (2005). Çocuk Gelişimi ve Eğitimi, İstanbul: Morpa Yayınları.

Bender, M., Valletutti, P.J., Baglin, C.A. (1996). “A Functional curriculum for teaching students with disabilities" self-care, motor skills, household management and living skills, Volume 1, third edition Austin: Texas.

Darıca, N. (2002). Okul Öncesi Eğitimcileri İçin Etkinlik Örnekleri Kılavuz Kitap. İstanbul: Koza Yayınları

Demiriz, S. ve Dinçer, Ç.(2000). “Okul Öncesi Dönem Çocuklarının Öz Bakım Becerilerinin Annelerinin Çalışıp Çalışmama Durumlarına Göre İncelenmesi". Hacettepe Üniversitesi Eğitim Fakültesi Dergisi,s.19.

Demiriz, S. ve Dinçer, Ç. (2001). 5-6 Yaş Çocuklarının Öz Bakım Becerilerinin Cinsiyet ve Okul Öncesi Eğitim Alma Durumlarına Göre İncelenmesi. Milli Eğitim Dergisi, s.150.

Dere, H. ve Poyraz, H. (2001). Okul Öncesi Ĕ̆itimin İlke ve Yöntemleri.

Ankara: Ana Yayıncilık.

Dinç, B. (2002). “Okul Öncesi Eğitimin 4-5 Yaş Çocuğunun Sosyal Gelişimine Etkileri Konusunda Öğretmen Görüşleri", Anadolu Üniversitesi Eğitim Bilimleri Enstitüsü İlköğretim Anabilim Dalı, Yayınlanmamış Yüksek Lisans Tezi, Eskişehir.

Einon, D. (1998). “Guide to Learning Early" Münich Deutschland

Ensari, B. (1997). "Okul Öncesi Eğitimi ve Araç-Gereçleri", Marmara Üniversitesi Güzel Sanatlar Enstitüsü, Yayınlanmamış Yüksek Lisans Tezi, İstanbul.

Erden, M. ve Akman, V. (1997). Ĕ̆itim psikolojisi gelişim öğrenme öğretme. İstanbul: Arkadaş Yayınevi

Fidan, N. ve Erden, M. (1993). Eğitime giriş. Ankara: Meteksan A.Ş.Yayınları.

Gazezoğlu, Ö. (2007). “Okul öncesi eğitim kurumlarnna devam eden 6 yaş çocuklarına öz bakım becerilerinin kazandırlmasında oyun yoluyla 
öğretimin etkisi", Dokuz Eylül Üniversitesi, Eğitim Bilimleri Enstitüsü, Yüksek Lisans Tezi, İzmir.

Geiger, B., Artz, L, Petri, C., Winnail, Mason, W. (2000). "Fun with handwashing education", ERIC: ED4447335.

Gönen, M. (1990). Çocuğun gelişmesinde okul öncesi eğitimin önemi Okul Öncesi Ĕ̆itim Dergisi, 39.

Güneyli, U. (1988). 4-6 Yaş Grubu Çocuklarında Beslenme Alışkanlıkları ve Bunu Etkileyen Etmenler Konusunda Bir Araştırma. Beslenme ve Diyet Dergisi, 17.

Karasar, N. (2002). Bilimsel Araştırma Yöntemi. Ankara: Nobel Yayın Dağıtım.

Katz, L.G. (1999). "Another look at what young children should be Learning", Databases/ERIC: ED453980.

Kingston, E. (1995). "Developing a program to improve toileting skills of prekindergarten handicapped students in a suburban elementary school", ERIC: ED385113.

Konya, S. (2007). "Kubaşık öğrenme etkinliklerinin beş yaş grubu öğrencilerinin öz Bakım becerilerinin gelişimine etkisi", Adnan Menderes Üniversitesi, Sosyal Bilimler Enstitüsü, Yüksek Lisans Tezi, Aydın.

Kurtuluş, E. (1999). “Okul öncesi eğitim kurumuna devam eden beş-altı yaş grubu çocuklarına yaratıcı etkinlikler yoluyla kavram (Zaman Kavramı) öğretilmesi", Marmara Üniversitesi, Eğitim Bilimleri Enstitüsü, Yayınlanmamış Yüksek Lisans Tezi, İstanbul.

Küçükali, R. (2010). Çocuklarda beslenme bozuklukları ve beslenmenin okul çocukları üzerindeki etkileri, Atatürk Üniversitesi, Kazım Karabekir Eğitim Fakültesi Dergisi, sayı:14.

Küçükturan, G. (2003). Okul Öncesi Fen Öğretiminde Bir Teknik: Analoji. Milli Eğitim Dergisi, Sayı:157. 
Lawatsh, E.D. (1990). "A Comparison of Two Teaching Strategies on Nutrition Knowledge Attitudes and food Behavior of Preschool Children", $\quad$ Society for Nutrition Education, 22

MEB, (2006). Okul Öncesi Eğitimi Genel Müdürlüğ̈̈, Okul Öncesi Eğitim Programı (36-72 Aylık Çocuklar İçin) Kitabı, Ankara: Devlet Kitapları Müdürlüğü.

Myers, R. (1990). “Erken çocukluk gelişimi ve eğitimde farklı modeller.” 1014 Eylül, Seminer Bildirileri, Unicef Yayını.

Oktay, A. (1983). Türkiye'de okul öncesi eğitimin dünü ve bugünü, Eğitim ve Bilim Dergisi, 7.

Oktay, A. (1993). "Okul Öncesi Eğitimi 1. Sempozyumu” Milli Eğitim Bakanlığı, Ankara: Okul Öncesi Eğitim Genel Müdürlüğü Yayınları.

Oktay, A. (2004). Yaşamın sihirli yılları, İstanbul: Epsilon Yayıncılık

Oğuzkan, Ş. ve Oral, G.(1983). Okul Öncesi Eğitimi, İstanbul: Milli Eğitim Yayınevi.

OOEGM (2006). Okul Öncesi Eğitim Programı (http://ooegm.meb.gov.tr/program.htm) adresinden 16.02.2011 tarihinde alınmıştır.

Önder, A. (2003). Okul öncesi çocukları için eğitici drama uygulamaları. İstanbul: Morpa Yayınları.

Öz, F. (1983). "Okulöncesi eğitim", Cumhuriyet Döneminde Eğitim, (Ed.: H. Sağlam), İstanbul: Milli Eğitim Basımevi.

Özen, Y. (2001). Yarına Kalmak Adına Sorumluluk Eğitimi, Ankara: Nobel Yayın Dağıtım Ltd. Şti..

Postacı, F.(1992). “Çocukluk Çağı Kazaları" Yüksek Lisans Tezi, İstanbul Üniversitesi Çocuk Sağllğı Enstitüsü, İstanbul 
Sahannon, B. ve Chen, A. (1988). "A Three-Year School-Based Nutrition Education Study", Journal of Nutrition Education.

Tamkavas, E. (2003). “5-6 Yaş Çocuklarının Öz Bakım Becerilerinin Cinsiyet ve Okul Öncesi Eğitim Alma Durumlarına Göre İncelenmesi", Yayınlanmamış Yüksek Lisans Tezi, Selçuk Üniversitesi Sosyal Bilimleri Enstitüsü.

TOS, F. (2001). Çocuğun Gelişiminde Okul Öncesi Ĕğitim. İstanbul: Kariyer Yayıncilik

Turan, F. (2004). Okul Öncesi Eğitim Kurumları Yönetmeliği ve Programının Değerlendirilmesi. Milli Eğitim Dergisi, Sayı:162.

Üstünova, E. (1998). “Okul Öncesi Eğitime Devam Eden Çocukların Annelerinin Ĕ̆itim Seviyelerine Göre Beklentileri", Marmara Üniversitesi Eğitim Bilimleri Enstitüsü, Yayınlanmamış Yüksek Lisans Tezi, İstanbul.

Varol, N. (2005). Beceri öğretimi ve öz bakım becerilerinin kazandırlması, Ankara: Kök Yayınclık

Yavuzer, H. (1979). Çocuk psikolojisi,İstanbul: Remzi Kitabevi

Yavuzer, H. (1984). Çocuk Psikolojisi. İstanbul: Altın Kitaplar Yayınevi.

Yavuzer, H. (1997). Çocuk Psikolojisi (14. Basım). İstanbul: Remzi Kitabevi.

Yavuzer, H. (2004) Ana-Baba ve Çocuk. İstanbul: Remzi Kitabevi.

Yavuzer, H. (2005) Bedensel, Zihinsel ve Sosyal Gelişimiyle Çocuğunuzun İlk 6 Yill. İstanbul: Remzi Kitabevi.

Yılmaz, N. (Edt: Sevinç, M.) (2003). Türkiye'de Okul Öncesi Eğitimi, Gelişim ve Eğitimde Yeni Yaklaşımlar. İstanbul: Morpa Yayınları.

Yörükoğlu, A.(1992). Değişen toplumda aile ve çocuk, Özgür Yayın Dağıtım: İstanbul. 